\title{
A Survey of Fertility Program Responses of Kentucky Dark Fire-Cured Tobacco (Nicotiana tabacum L.) Yield and Quality for Cigars Manufacture in the Benevento Province (Southern Italy) *
}

\author{
by \\ Maria Isabella Sifola ${ }^{1}$, Linda Carrino ${ }^{1}$, Eugenio Cozzolino ${ }^{2}$, Sara Ianuario $^{1}$, Andrea Lucibelli ${ }^{1}$, and Adele Coppola ${ }^{1}$ \\ ${ }^{1}$ Department of Agricultural Sciences, University of Napoli Federico II, Via Università 100, 80055 Portici (Napoli), Italy \\ ${ }^{2}$ CREA-CI (Council for Agricultural Research and Economics - Research Institute for Cereals and Industrial Crops) Via \\ Torrino 2, 81100 Caserta, Italy
}

\section{SUMMARY}

Nitrogen $(\mathrm{N})$ fertilization of Kentucky dark fire-cured tobacco can be used to increase weight of high quality cured leaves for cigar manufacture. We conducted field experiments at 11 different locations in the province of Benevento (Southern Italy) where the following four $\mathrm{N}$ treatments were compared: 1) unfertilized control (N0); 2) a site-specific $\mathrm{N}$ rate, calculated by a $\mathrm{N}$ fertilization plan (NFP) based on physical and chemical soil characteristics, which ranged between 113 and $145 \mathrm{~kg} \mathrm{~N} \mathrm{ha}^{-1}$; 3) $200 \mathrm{~kg} \mathrm{~N} \mathrm{ha}^{-1}$ (rate commonly used by farmers, N200); 4) $100 \mathrm{~kg} \mathrm{~N} \mathrm{ha}^{-1}$ (half of the rate commonly used by farmers, $\mathrm{N} 100$ ). Yields of the following five commercial quality categories of cured leaves were measured: i) wrappers, ii) heavy filler (Fh), iii) light filler (Fl), iv) heavy shredded (Sh) and v) light shredded (Sl). Fh cured products of B1, B4, B6 and B10 locations were analyzed for: total alkaloids, reducing sugars, chlorides, total $\mathrm{N}$ (Kjeldahl), ammonium-N $\left(\mathrm{NH}_{4}-\mathrm{N}\right)$, nitrate- $\mathrm{N}\left(\mathrm{NO}_{3}-\mathrm{N}\right)$, and tobacco specific nitrosamines (TSNA). Color parameters: Lightness $(\mathrm{L})$, Chroma $(\mathrm{C})$ and Hue $(\mathrm{H})$ were determined on five cured leaves / plot of both Fh and Fl types at B1, B2, B3, B6, B8 and B10. A blind evaluation of cured leaves collected across locations was conducted by a panel test who considered the main basic characteristics of cured leaves (stalk position, leaf structure, texture, etc.). The total yield of cured products increased with fertilization across locations, up to NFP treatment, without any statistically significant increase at N200 treatment. Fertilization increased yield of wrappers at B1 up to NFP treatment $\left(113.5 \mathrm{~kg} \mathrm{~N} \mathrm{ha}^{-1}\right)$, without any significant increase at N200 treatment. Yield of light filler product was positively influenced by fertilization up to the maximum dose only in 5 out of 11 locations. Total alkaloids significantly increased with increasing fertilization up to $100 \mathrm{~kg} \mathrm{~N} \mathrm{ha}^{-1}$ without any significant changes at higher $\mathrm{N}$ rate. Fertilization hardly increased L and C of Fl leaves, which appeared light-brown but brilliant-colored. There was a reduction in the $\mathrm{H}$ value of $\mathrm{Fh}$ products which indicated a darker tone of those leaves with respect to $\mathrm{Fl}$. Increasing $\mathrm{N}$ rate affected production costs more than revenues. According to agronomic results, in most locations the best results in terms of net revenues were obtained by NFP treatment. Considering that $\mathrm{N}$ rates above the NFP would disqualify growers from the economic aids provided by EU agrienvironmental measures, by economic point of view the NFP treatment would be recommended over the current grower standard (N200). [Beitr. Tabakforsch. Int. 28 (2018) 14-29] 
KEYWORDS:

Alkaloids, cured products, economic profitability, nitrogen, tobacco specific nitrosamines (TSNA), TOSCANO ${ }^{\circledR}$ Cigar

\section{ZUSAMMENFASSUNG}

Die Düngung mit Stickstoff (N) kann bei Kentucky Dark Fire-Cured Tabak eingesetzt werden, um das Gewicht von hochwertigen getrockneten Blättern für die Zigarrenherstellung zu erhöhen. Wir führten Feldexperimente an 11 verschiedenen Orten in der Provinz Benevento (Süditalien) durch, wo die folgenden vier N-Behandlungen verglichen wurden: 1) ungedüngte Kontrolle (N0); 2) eine standortspezifische N-Rate zwischen 113 und $145 \mathrm{~kg} \mathrm{~N} \mathrm{ha}^{-1}$, berechnet anhand eines N-Düngungsplans (NFP) basierend auf physikalischen und chemischen Bodeneigenschaften; 3 ) $200 \mathrm{~kg} \mathrm{~N} \mathrm{ha}^{-1}$ (häufig von Landwirten verwendet, N200); 4) $100 \mathrm{~kg} \mathrm{~N} \mathrm{ha}^{-1}$ (die Hälfte der von den Landwirten üblicherweise verwendeten Rate, N100). Die Ausbeuten der folgenden fünf kommerziellen Qualitätskategorien von getrockneten Blättern wurden gemessen: i) Umhüllungen, ii) schwerer Füllstoff (Fh), iii) leichter Füllstoff (Fl), iv) grob zerkleinert (Sh) und v) fein zerkleinert (Sl). Fh-getrocknete Produkte der Positionen B1, B4, B6 und B10 wurden analysiert auf: Gesamtalkaloide, reduzierende Zucker, Chloride, Gesamt-N (Kjeldahl), Ammonium-N $\left(\mathrm{NH}_{4}-\mathrm{N}\right)$, Nitrat-N $\left(\mathrm{NO}_{3}-\mathrm{N}\right)$ und tabak-spezifische Nitrosamine (TSNA). Farbparameter: Helligkeit (L), Chroma (C) und Farbton $(\mathrm{H})$ wurden an fünf getrockneten Blättern / Plot der beiden Fh- und Fl-Typen bei B1, B2, B3, B6, B8 und B10 bestimmt. Durch einen Paneltest wurde eine Blindbewertung der getrockneten Blätter, die über die Standorte gesammelt wurden, durchgeführt, welcher die Hauptgrundmerkmale der getrockneten Blätter (Stielposition, Blattstruktur, Textur usw.) berücksichtigte. Die Gesamtausbeute der getrockneten Produkte stieg mit der Düngung an den verschiedenen Standorten bis zur NFP-Behandlung an, ohne statistisch signifikante Zunahme bei der Behandlung mit N200. Die Düngung erhöhte den Ertrag der Umhüllungen bei B1 bis zur NFP-Behandlung $\left(113,5 \mathrm{~kg} \mathrm{~N} \mathrm{ha}^{-1}\right)$, ohne eine signifikante Zunahme bei der N200-Behandlung. Die Ausbeute an leichtem Füllstoff wurde durch die Düngung bis zur maximalen Dosis nur an 5 von 11 Stellen positiv beeinflusst. Die Gesamtalkaloide stiegen signifikant mit zunehmender Düngung bis $100 \mathrm{~kg} \mathrm{~N}^{-1}$ ohne signifikante Veränderungen bei höherer N-Rate. Die Düngung erhöhte kaum L und $\mathrm{C}$ der F1-Blätter, die hellbraun, aber brillant gefärbt erschienen. Es gab eine Verringerung des H-Wertes von FhProdukten, was einen dunkleren Ton dieser Blätter in Bezug auf F1 anzeigte. Die Erhöhung der N-Rate beeinflusste die Produktionskosten stärker als die Einnahmen. Den agronomischen Ergebnissen zufolge wurden an den meisten Standorten die besten Ergebnisse in Bezug auf die Nettoeinnahmen durch die NFP-Behandlung erzielt. In Anbetracht der Tatsache, dass N-Werte über dem NFP die Erzeuger von den Wirtschaftsbeihilfen der EU-Agrarumweltmaßnahmen ausschließen würden, wäre die NFP-Behandlung aus wirtschaftlicher Sicht gegenüber dem derzeitigen Anbaustandard (N200) zu empfehlen. [Beitr. Tabakforsch. Int. 28 (2018) 14-29]

\section{RESUME}

La $\mathrm{N}$ fertilisation du tabac brun séché au feu du Kentucky peut être utilisée pour augmenter le poids des feuilles séchées de haute qualité pour la fabrication de cigares. Nous avons mené des expériences sur le terrain à 11 endroits différents dans la province de Benevento (Italie du $\mathrm{Sud}$ ) où les quatre traitements $\mathrm{N}$ suivants ont été comparés: 1) témoin non fertilisé (N0); 2) un taux d'azote spécifique au site, calculé par un plan de fertilisation azotée (NFP) basé sur les caractéristiques physiques et chimiques du sol, compris entre 113 et $145 \mathrm{~kg} \mathrm{~N} \mathrm{ha}^{-1}$; 3) $200 \mathrm{~kg} \mathrm{~N} \mathrm{ha}^{-1}$ (taux couramment utilisé par les agriculteurs, N200); 4) $100 \mathrm{~kg} \mathrm{~N} \mathrm{ha}^{-1}$ (la moitié du taux couramment utilisé par les agriculteurs, N100). Les rendements des cinq catégories de qualité commerciale de feuilles séchées suivantes ont été mesurés: i) enveloppes, ii) charge lourde (Fh), iii) charge légère ( $\mathrm{Fl})$, iv) déchiqueté lourd (Sh) et $\mathrm{v}$ ) déchiqueté léger (S1). Les produits Fh guéris des sites B1, B4, B6 et B10 ont été analysés pour: alcaloïdes totaux, sucres réducteurs, chlorures, $\mathrm{N}$ total (Kjeldahl), ammonium- $\mathrm{N}\left(\mathrm{NH}_{4}-\mathrm{N}\right)$, nitrate- $\mathrm{N}\left(\mathrm{NO}_{3}-\mathrm{N}\right)$ et spécifique au tabac nitrosamines (TSNA). Paramètres de couleur: La luminosité (L), la chrominance $(\mathrm{C})$ et la teinte $(\mathrm{H})$ ont été déterminées sur cinq feuilles / parcelles durcies des types Fh et Fl en B1, B2, B3, B6, B8 et B10. Une évaluation en aveugle des feuilles séchées collectées à travers les sites a été réalisée par un test de panel qui a examiné les principales caractéristiques de base des feuilles séchées (position de la tige, structure de la feuille, texture, etc.). Le rendement total des produits durcis a augmenté avec la fertilisation, à travers les sites, jusqu'au traitement PFN, sans augmentation statistiquement significative au traitement N200. La fertilisation augmente le rendement des enveloppes à B1 jusqu'au traitement NFP $\left(113,5 \mathrm{~kg} \mathrm{~N} \mathrm{ha}^{-1}\right)$, sans augmentation significative au traitement N200. Le rendement du produit de remplissage léger a été positivement influencé par la fertilisation jusqu'à la dose maximale seulement dans 5 des 11 emplacements. Les alcaloïdes totaux augmentaient significativement avec l'augmentation de la fertilisation jusqu'à $100 \mathrm{~kg} \mathrm{~N}$ ha $^{-1}$ sans changements significatifs à un taux d'azote plus élevé. La fertilisation n'augmentait guère les feuilles $\mathrm{L}$ et $\mathrm{C}$ des feuilles $\mathrm{Fl}$, qui paraissaient brun clair mais brillantes. Il y avait une réduction de la valeur $\mathrm{H}$ des produits Fh qui indiquait un ton plus foncé de ces feuilles par rapport à Fl. L'augmentation du taux $\mathrm{N}$ a affecté les coûts de production plus que les revenus. Selon les résultats agronomiques, dans la plupart des endroits, les meilleurs résultats en termes de revenus nets ont été obtenus par le traitement NFP. Si l'on considère que les taux d'azote audessus du PFN priveraient les producteurs des aides économiques accordées par les mesures agroenvironnementales de l'UE, d'un point de vue économique, le traitement PFN serait recommandé par rapport à la norme actuelle (N200). [Beitr. Tabakforsch. Int. 28 (2018) 14-29]

\section{INTRODUCTION}

Tobacco has been grown for centuries in Italy, where in many regions it has contributed substantially to income, employment, and cultural heritage. EU Common Agricultu- 
ral Policy (CAP) reform, which eliminated coupled subsidies in 2010, substantially reduced tobacco cultivation in Europe (1). Continued tobacco growing is currently dependent on the capability of tobacco growers and / or leaf dealers to find innovative solutions to produce high quality products while taking into account economic, environmental, and social aspects of crop sustainability. In Italian regions of Campania, Tuscany, Veneto, Umbria and Lazio, where tobacco is mainly grown, the application of the last EU CAP reform produced the most significant contractions of both areas planted and overall production in the period 2008-2010 (1) due to reorganization processes to grow other more profitable crops. Unfortunately, both types of contractions still occurred in $2012(-27 \%)$ (1). The decrease in tobacco production differed among types, with the greatest declines for light air-cured tobacco ( $-17.5 \%$ in 2010 compared to 2009; Group II) and the least for fire-cured tobacco ( $-0.8 \%$; Group IV) (1). The latter tobacco type is currently used for the production of TOSCANO $^{\circledR}$ cigars by Manifatture Sigaro Toscano Spa (MST), a company of the Maccaferri Industrial Group, and is mainly cultivated in Central and Southern Italy (Tuscany and Campania region, respectively).

Fire-cured tobacco of Campania region, concentrated in the Benevento province, is successfully used to manufacture particular types of TOSCANO ${ }^{\circledR}$ cigars, TOSCANO ${ }^{\circledR}$ "Garibaldi", which are lighter in color and sweeter in taste than TOSCANO ${ }^{\circledR}$ "Classico".

However, the extraordinary lightness of Benevento leaf restricts their potential use in the TOSCANO ${ }^{\circledR}$ cigar industry. Heavier-bodied leaves would have a greater economic value with respect to the lighter ones since they could be used to manufacture a wider range of TOSCANO $^{\circledR}$ cigar types, thus producing higher incomes for Campania tobacco growers (2). Heaviness is one of the morphological parameter that defines the quality of tobacco products $(3,4)$, and is directly related to the socalled leaf body. "Body" is reported to refer to the thick- ness, density, or weight of a tobacco leaf (5). Thickness, which appears positively related to the weight-per-unit leaf area, is properly considered a measure of "body" (3). Both thickness and weight generally increase with increasing nitrogen $(\mathrm{N})$ fertilization rates $(3,6,7)$. High amounts of $\mathrm{N}$ compounds, especially proteins, are generally accumulated in the leaves at high rates of $\mathrm{N}$, thus producing more dense tissues (8). However, heavier tissues positively contribute to leaf quality only when they have open leaf intracellular spaces and do not reduce the burning capacity (9). More-over, it is likely that if $\mathrm{N}$ rates are increased to excessive $\mathrm{N}$ levels, the rate of leaf ripening slows (10) and the potential for negative environmental impact increases. In addition, the best results are obtained when irrigation practices are also efficiently applied.

This paper focuses on the opportunity of a revision of the total fertility program adjusting $\mathrm{N}$ fertilization of Kentucky dark fire-cured tobacco cultivation in the Benevento province (Southern Italy) to increase the weight of high quality cured leaves for cigar manufacture without producing any negative impacts on the quality of cured products or environment. Considering the potential higher economic value of heavier leaves compared to lighter cured products (2), we also reported some economic evaluation of the results.

\section{MATERIALS AND METHODS}

\section{Plant material, experimental conditions and climate}

In 2014, experiments were conducted at 11 locations in the Benevento province (location codes B1 to B11) on dark firecured Kentucky tobacco (Nicotiana tabacum L.), using local ecotypes of Riccio Beneventano or cv. SKL (Bartolucci). Soil properties of each location are reported in Table 1. At each location the following four nitrogen $(\mathrm{N})$ treatments were compared:

Table 1. Physical and chemical characteristics in the $\mathbf{0}-\mathbf{0 . 3} \mathbf{~} \mathbf{m}$ top soil layer in $\mathbf{2 0 1 4}$. B1, B2, B3, B4, B5, B6, B7, B8, B9, B10 and B11 are location codes.

\begin{tabular}{|c|c|c|c|c|c|c|c|c|c|c|c|}
\hline Location & $\mathrm{B} 1$ & $\mathrm{~B} 2$ & B3 & B4 & B5 & $\mathrm{B} 6$ & $\mathrm{~B} 7$ & B8 & B9 & B10 & $\mathrm{B} 11$ \\
\hline Sand (\%) & 58.6 & 61.2 & 60.8 & 66.6 & 60.7 & 44.5 & 61.3 & 58.2 & 65.3 & 48.1 & 42.2 \\
\hline Silt (\%) & 22.0 & 16.2 & 17.3 & 16.3 & 16.3 & 26.5 & 19.3 & 21.8 & 17.3 & 16.2 & 24.2 \\
\hline Clay (\%) & 19.4 & 22.0 & 21.2 & 17.2 & 23.0 & 29.0 & 19.3 & 20.0 & 17.3 & 35.7 & 33.7 \\
\hline Lime (\%) & 8.92 & n.d. & 16.5 & 15.0 & 0.5 & 6.8 & 8.0 & n.d. & 2.7 & 1.8 & 4.5 \\
\hline $\mathrm{pH}$ & 7.5 & 7.5 & 7.7 & 7.5 & 7.11 & 7.6 & 8.1 & 7.2 & 7.4 & 7.5 & 7.9 \\
\hline OM (\%) & 1.913 & 1.517 & 1.373 & 1.310 & 0.650 & 1.157 & 2.063 & 0.960 & 1.283 & 1.407 & 0.647 \\
\hline $\mathrm{P}_{2} \mathrm{O}_{5}(\mathrm{ppm})$ & 19.5 & 52.4 & 36.1 & 19.1 & 29.2 & 29.9 & 46.3 & 104.0 & 52.1 & 61.9 & 48.1 \\
\hline $\mathrm{K}_{2} \mathrm{O}(\mathrm{ppm})$ & 152.1 & 122.2 & 97.6 & 96.8 & 113.3 & 118.2 & 306.1 & 129.9 & 146.4 & 145.2 & 104.5 \\
\hline N (Kjeldahl) (\%) & 0.105 & 0.097 & 0.082 & 0.083 & 0.060 & 0.096 & 0.122 & 0.082 & 0.105 & 0.109 & 0.056 \\
\hline $\mathrm{NO}_{3}-\mathrm{N}(\mathrm{ppm})$ & 14.0 & 8.0 & 9.0 & 8.3 & 20.3 & 9.7 & 13.3 & 12.7 & 16.3 & 19.3 & 19.7 \\
\hline $\mathrm{NH}_{4}-\mathrm{N}(p p m)$ & 12.8 & 15.3 & 14.3 & 14.3 & 18.7 & 15.7 & 18.0 & 19.7 & 18.7 & 15.0 & 11.0 \\
\hline$E C_{e}\left(\mathrm{dS} \mathrm{m}^{-1}\right)$ & 1.80 & 1.41 & 1.61 & 1.79 & 1.01 & 1.61 & 1.78 & 1.04 & 1.50 & 1.52 & 1.70 \\
\hline FC (\% p.s.) & 28 & 25 & 27 & 23 & 25 & 32 & 28 & 25 & 23 & 35 & 33 \\
\hline WP (\% p.s.) & 16 & 15 & 15 & 13 & 15 & 19 & 16 & 14 & 13 & 22 & 20 \\
\hline
\end{tabular}

OM organic matter

$\mathrm{EC}_{\mathrm{e}}$ electrical conductivity of saturated soil-paste

FC field capacity (0.03 MPa)

WP wilting point (1.5 Mpa)

n.d. not detected 
1. an unfertilized control (N0);

2. a site-specific $\mathrm{N}$ dose, calculated by a $\mathrm{N}$ fertilization plan (NFP, http://www.agricoltura.regione.campania.it/ concimazione/pdf/guida_2017.pdf) at each location on the basis of physical and chemical soil characteristics and soil $\mathrm{N}$ balance;

3. $200 \mathrm{~kg} \mathrm{~N} \mathrm{ha}^{-1}$ (rate commonly used by farmers as optimal, N200);

4. $100 \mathrm{~kg} \mathrm{~N} \mathrm{ha}^{-1}$ (half of the rate commonly used by the farmers, N100).

Each treatment was replicated three times at each location.

For the NFP treatment, the following contributions and losses were considered in the soil $\mathrm{N}$ balance:

- contributions from the mineralization of the organic matter;

- residues from the previous year's crop;

- nitrogen from organic fertilization carried out in previous years;

- contributions from atmospheric depositions (precipitation, etc.);

- decrease of crop requirements;

- decrease of fixed assets and deep dispersion;

- decrease of leaching.

The site specific $\mathrm{N}$ doses were: 113.5 (B1), 131.6 (B2), 141.5 (B3), 142.0 (B4), 119.3 (B5, B6 and B7), 134.0 (B8), 126.6 (B9), 131.4 (B10) and 145.3 (B11) $\mathrm{kg} \mathrm{N} \mathrm{ha}^{-1}$.

At all locations, $\mathrm{N}$ fertilizer was applied according to the following protocol: 1/3 at transplanting (end of May - mid June); $1 / 3$ at the first weeding/tamping (end of June); $1 / 3$ at plant topping (end of July - beginning of August) dividing the total doses into three applications of equal amounts.

In the total fertilization program, the following fertilizer product combinations, according to standard practices on site, were used: 1) Nitrofoska 12/12/17 (BASF SE, Ludwigshafen, Germany) at transplanting, Entec 26 (BASF SE, Ludwigshafen, Germany) at weeding and potassium nitrate
13/0/46 (Multi-K, Haifa-Group, Israel) at topping at B1, B2, B3 and B4 locations; 2) Nitrofoska 12/12/17 at transplanting, ammonium nitrate 26 at weeding, potassium nitrate $13 / 0 / 46$ and ammonium nitrate 26 at topping at B5, B6, B7, B8, B9, B10, and B11.

Due to the use of complex fertilizers at transplanting and potassium nitrate at side-dress, increasing amounts of $\mathrm{P}_{2} \mathrm{O}_{5}$ (ranging between 20 and $67 \mathrm{~kg} \mathrm{ha}^{-1}$ ) and $\mathrm{K}_{2} \mathrm{O}$ (Table 2) were also applied with increasing doses of $\mathrm{N}$.

Seedlings were transplanted between May (at B1, B3, B4, B9, and B10) and June (at B2, B5, B6, B7, B8, B11) (Table 2) with a plant spacing between rows $\times$ within row which varied from $1.15 \mathrm{~m} \times 1.0 \mathrm{~m}(\mathrm{~B} 10)$ to $0.92 \mathrm{~m} \times 0.83 \mathrm{~m}$ (B5) (Table 2) resulting in a range of plant densities from 8,696 to 13,089 plants ha $^{-1}$, respectively.

After seedling establishment, plants were regularly irrigated up to final harvest. Seasonal volumes, empirically determined, varied from 800 (B4) to $2500 \mathrm{~m}^{3} \mathrm{ha}^{-1}$ (B1 and B3), and were applied by a minimum of 3 (B2 and B7) up to a maximum of 7 (B8) waterings. Irrigation water was generally applied by sprinklers with the exception of B4 and B6 locations where plants were also drip-irrigated (Table 2). To evaluate the empirical irrigation, irrigation volumes were also calculated by crop evapotranspiration $\left(E_{c}\right)$, estimated from HARGREAVES (11) multiplied by crop coefficients $\left(k_{c}\right)$ of tobacco (12), whose values changed according to the stage of plant development. The $\mathrm{k}_{\mathrm{c}}$ were 0.4 at transplanting, $0.7-0.8$ during rapid stem elongation, $1.0-1.2$ at flowering, $1.0-0.9$ at full maturity and $0.85-0.75$ at harvest (12). Irrigation intervals were calculated considering a water depletion of $40 \%$ of available water in a soil profile ranging between $0-0.15 \mathrm{~m}$ depth at transplanting and $0-0.50 \mathrm{~m}$ at maximum plant development (13). In late July-early August, plants were topped at a height of 15-17 leaves per plant, and they were harvested one or two times, depending on the location, starting from the begin-

Table 2. Transplanting date, plant spacing, crop duration, $\mathrm{K}_{2} \mathrm{O}$ fertilization, irrigation volumes and intervals for the different experimental locations in 2014. $\mathrm{N}$ treatments: 0,100 and $200 \mathrm{~kg} \mathrm{~N}^{-1}$; NFP, $\mathrm{N}$ dose by $\mathrm{N}$ fertilization plan. B1, B2, B3, B4, B5, B6, B7, $\mathrm{B} 8, \mathrm{~B} 9, \mathrm{~B} 10$ and B11 are location codes.

\begin{tabular}{|c|c|c|c|c|c|c|c|c|c|c|}
\hline \multirow[b]{2}{*}{ Locations } & \multirow[b]{2}{*}{$\begin{array}{l}\text { Transplanting } \\
\text { date }\end{array}$} & \multirow[b]{2}{*}{$\begin{array}{l}\text { Plant } \\
\text { spacing } \\
\mathrm{m} \times \mathrm{m}\end{array}$} & \multirow[b]{2}{*}{$\begin{array}{c}\text { Crop } \\
\text { duration } \\
\text { (days) }\end{array}$} & \multicolumn{4}{|c|}{$\mathrm{K}_{2} \mathrm{O}$ applied $\left(\mathrm{kg} \mathrm{ha}^{-1}\right)$} & \multicolumn{3}{|c|}{ Irrigation } \\
\hline & & & & No & N100 & NFP & N200 & $\begin{array}{c}\text { No. } \\
\text { Waterings }\end{array}$ & $\begin{array}{l}\text { Watering } \\
\text { volume } \\
\left(\mathrm{m}^{3} \mathrm{ha}^{-1}\right)\end{array}$ & $\begin{array}{c}\text { Seasonal } \\
\text { volume } \\
\left(\mathrm{m}^{3} \mathrm{ha}^{-1}\right)\end{array}$ \\
\hline B1 & $27 / 05-3 / 06$ & $0.90 \times 0.90$ & 98 & - & 145.8 & 188.8 & 264.6 & 5 & 500 & 2500 \\
\hline B2 & $12 / 06$ & $1.00 \times 1.00$ & 105 & - & 156.2 & 217.6 & 312.5 & 3 & 400 & 1200 \\
\hline B3 & $27 / 05$ & $0.90 \times 0.90$ & 97 & - & 175.6 & 234.0 & 351.2 & 5 & 500 & 2500 \\
\hline B4 & $27 / 05$ & $0.90 \times 0.90$ & 106 & - & 154.4 & 234.7 & 285.3 & 4 & $\begin{array}{l}400 \\
200^{b}\end{array}$ & $\begin{array}{l}1600 \\
800^{b}\end{array}$ \\
\hline B5 & $10 / 06$ & $0.92 \times 0.83$ & 115 & - & 79.5 & 101.9 & 158.4 & 4 & 300 & 1200 \\
\hline B6 & $03 / 06$ & $1.00 \times 0.80$ & 119 & - & 79.5 & 101.9 & 158.4 & 4 & 300 & 1200 \\
\hline B7 & $07 / 06$ & $0.95 \times 0.90$ & 103 & - & 79.5 & 101.9 & 158.4 & 3 & 300 & 900 \\
\hline B8 & $03 / 06$ & $1.00 \times 0.90$ & 111 & - & 77.6 & 125.6 & 154.4 & 7 & 300 & 2100 \\
\hline B9 & $14 / 05$ & $1.00 \times 0.90$ & 139 & - & 72.5 & 122.2 & 154.4 & 5 & 300 & 1500 \\
\hline B10 & $20 / 05$ & $1.15 \times 1.00$ & 119 & - & 77.3 & 124.6 & 154.4 & 5 & 320 & 1600 \\
\hline B11 & $05 / 06$ & $1.10 \times 0.98$ & 142 & - & 74.9 & 129.8 & 150.8 & 4 & 300 & 1200 \\
\hline
\end{tabular}

\footnotetext{
${ }^{a}$ Irrigation volume never changed between waterings.

${ }^{b}$ At this location only the N200 plots were drip-irrigated. With drip-irrigation, $50 \%$ of the irrigation water was saved by farmers, due to both high efficiency of water distribution and reduced area of soil wetted.
} 
ning of September up to end of October, with a crop duration ranging between 97 and 142 days (Table 2). In particular, leaves were hand-picked and manually or mechanically pierced and threaded together before firecuring, depending on locations. During the growing season, temperatures were particularly high in July and August and higher than $30^{\circ} \mathrm{C}$ in 17 out of 31 days in July and for the entire month of August. Cumulative rainfall was $262 \mathrm{~mm}$ from May to October. Rainfall events were well distributed in May, but were concentrated in the months of July (one event of $52.6 \mathrm{~mm}$ in the second 10-day period out of $89.8 \mathrm{~mm}$ monthly total amount) and August (two events, of about $17 \mathrm{~mm}$ each, in the first 10-day period). In July rainfall events were more abundant than the 30-year average ( $89.8 \mathrm{~mm}$ vs. $26 \mathrm{~mm}$ ) at each location.

\section{Plant growth, leaf curing, yield and quality}

In 4 out of 11 locations (B1, B4, B6, and B10) standard and homogenous cultivation techniques were used and one plant per plot was harvested for growth analysis at about 2-week intervals starting from the rosette stage (10 days after transplanting (DAT), at B6 and B10; 17 DAT at B1 and B4) until final harvest. Plants were weighed and dried at $60{ }^{\circ} \mathrm{C}$ to constant weight to calculate dry mass $\left(\mathrm{DM}, \mathrm{g}\right.$ plant $\left.^{-1}\right)$. Leaf area $\left(\mathrm{LA}, \mathrm{cm}^{2}\right.$ plant $\left.^{-1}\right)$ was measured by a LI-COR 3100 (LI-COR Inc., Lincoln NE, USA) at 32 (B6 and B10) and 39 (B1 and B4) DAT, and the specific leaf weight ( $\mathrm{SLW}, \mathrm{mg} \mathrm{DM} \mathrm{cm} \mathrm{cm}^{-2} \mathrm{LA}$ ) calculated at those respective dates.

At final harvest, leaves from the central part of each plot (18 to $50 \mathrm{~m}^{2}$, depending on the location) were freshweighed and appropriately arranged to be fire-cured in barns according to a standard procedure, which included four phases (leaf yellowing, leaf browning, drying of the lamina, drying of the midrib) and lasted 15-20 days (14). After curing was completed, yields of cured products was determined at 19\% standard moisture. Total yields were calculated by summing the following five different types of cured leaves: i) wrappers, ii) heavy and light filler (Fh and Fl), iii) heavy and light shredded type (Sh and Sl). Cured products of Fh type (collected at B1, B4, B6, and B10 locations) were analyzed for total alkaloids, reducing sugars, chlorides, total $\mathrm{N}$ (Kjeldahl), ammonium-N $\left(\mathrm{NH}_{4}-\mathrm{N}\right)$ and nitrate- $\mathrm{N}\left(\mathrm{NO}_{3}-\mathrm{N}\right)$, and tobacco specific nitros-amines (TSNA). A continuous flow analyzer was used to determine total alkaloids, reducing sugars, chlorides, and $\mathrm{NH}_{4}-\mathrm{N}$. Total alkaloids, expressed as nicotine, were determined by CORESTA Recommended Method No. 85 (15). In brief, an aqueous tobacco extract was analyzed by reaction with sulphanilic acid and cyanogen chloride. The colored complex was read at 460 $\mathrm{nm}$ and nicotine was expressed as \% dry weight (d.w.). Reducing sugars were determined using the CORESTA Recommended Method No. 38 (15) by preparing a tobacco extract in a $5 \%$ acetic acid solution which was subsequently analyzed by reaction with $p$-hydroxybenzoic acid hydrazide in a basic medium at $85^{\circ} \mathrm{C}$. The yellow colored complex (osazone) was read at $410 \mathrm{~nm}$ and results were expressed as \% d.w.. Chlorides (\% d.w.) were determined by preparing an aqueous tobacco extract which was subsequently analyzed in the flow system by reaction with mercuric thiocyanate and ferric nitrate to give a colored complex which was then read at $460 \mathrm{~nm}$. Nitrate content of cured tobacco products was determined according to the CORESTA Recommended Method No. 36 (15), after a reduction of nitrate to nitrite, using hydrazinium sulphate in the presence of a copper catalyst, and a reaction with sulphanilamide to form the diazo compound. Then, a coloured complex formed after the addition of $N$-1-naphthylethylenediamine dihydrochloride and was read at $520 \mathrm{~nm}$. Ammonium-N (\% d.w.) was determined on an aqueous tobacco extract which was then analyzed by reaction with sodium salicylate and sodium hypochlorite in alkaline medium at $50{ }^{\circ} \mathrm{C}$. The final colored complex was read at $630 \mathrm{~nm}$.

The tobacco specific nitrosamines (TSNA) were determined according to the CORESTA Recommended Method No. 72 (15) by adding deuterated standards to the tobacco tissues. Then, an extract in a buffer solution was prepared and filtered using $0.45 \mu \mathrm{m}$ membrane filters before analysis by a liquid chromatography coupled to a triple quadrupole mass spectrometry (LC-MS/MS). Individual TSNA ( $N$-nitrosonornicotine [NNN], $N$-nitrosoanabasine [NAB], $N$-nitrosoanatabine [NAT] and 4- $(N-$ methylnitrosoamino)-1-(3-pyridyl)-1-butanone [NNK]) were expressed in ng TSNA / $g$ d.w.. Cured products of Fl types from the same locations were analysed for their content of total and nitrate- $\mathrm{N}$ which were determined as previously reported (16).

At locations B1, B2, B4, B6, B8, and B10, color parameters $\mathrm{L} *$ (lightness), $\mathrm{a} *$ (green / red) and $\mathrm{b} *$ (blue / yellow) (16) of five cured leaves of Fh and Fl of each plot were measured at three locations along the leaf's long axis (at basal, medium and apical leaf lamina portions) with a colorimeter (Chromameter CR-210, Minolta, Hannover, Germany) containing an optical sensor of 8 $\mathrm{mm}$ diameter. Chroma $\left(\mathrm{C} ; \sqrt{ } \mathrm{a}^{2}+\mathrm{b}^{2}\right.$, color purity / saturation) and Hue $(\mathrm{H} ; \operatorname{atan} 2[\mathrm{~b}, \mathrm{a}])$ were calculated $(17,18)$ on each point and measures of each leaf were then averaged. A color quality index was calculated using the first principal component of $\mathrm{L}, \mathrm{C}$, and $\mathrm{H}$, adjusted as absolute values and normalized to a centesimal scale, as follows:

$\frac{P C 1 a-\min (P C 1 a)}{\max (P C 1 a)-\min (P C 1 a)} \times 100$

where $\mathrm{PC} 1$ is the principal component of $\mathrm{L}, \mathrm{C}$ and $\mathrm{H}$, ranging from -4.88 to -2.65 , and $\mathrm{PC} 1 \mathrm{a}$ is equal to $\mathrm{PC} 1+\mathrm{a}$ (absolute value).

Cured leaves of Fh, Sh, Fl, and Sl types, collected at each location, were also subjected to a blind evaluation based on a consensus between two experts who considered the following 8 main basic characteristics of cured leaves: i) crown belonging, ii) color, iii) structure and texture, iv) degree of ripeness, v) elasticity, vi) lamina integrity, vii) handling defects, viii) veins incidence.

Expert evaluation also aimed to verify the accuracy of different growers to separate heavy and light cured leaves of different types and to arrange leaves in homogeneous groups before selling, as the more homogeneous / properly sorted groups will receive a higher selling price (2). For this latter reason, the evaluation was made both before and 
after a training activity which aimed to improve samples homogeneity at each location. Results of the economic effect of training activity were previously reported (2).

\section{Soil sampling and analyses}

After final harvest, soil samples were collected at two depths (0-0.3 and 0.3-0.6 m) from the central part of each plot at 11 locations to determine the residual content of mineral $\mathrm{N}\left(\mathrm{NO}_{3}-\mathrm{N}\right.$ and $\left.\mathrm{NH}_{4}-\mathrm{N}\right)$ in soils. Both $\mathrm{NO}_{3}-\mathrm{N}$ and $\mathrm{NH}_{4}-\mathrm{N}$ were determined spectrophotometrically (Hach Company, Loveland, Colorado, USA) as previously reported (16).

\section{Economic data collection}

To assess the economic effects of $\mathrm{N}$ fertilization treatments at different locations, a simple partial budgeting approach was followed, which allowed comparison of the expected profitability of $\mathrm{N}$ fertility alternatives within revised total fertilization programs (19). The only information required was the difference in costs and revenues of proposed alternatives (each $\mathrm{N}$ fertilization treatment).

In our experiment, the effect of $\mathrm{N}$ fertilization treatments implied on one side the use of different rates of $\mathrm{N}$ and on the other side a change in quantity and / or quality of the final product. The economic analysis only takes into account the costs for $\mathrm{N}$ fertilization and the revenues obtained by different product types. Thus, the assessment of the most profitable alternative of $\mathrm{N}$ fertilization was based on the comparison of the revenues net of $\mathrm{N}$ fertilization costs. Therefore, total revenues and fertilization costs were estimated with reference to each $\mathrm{N}$ fertilization treatment, the difference between them were computed ("net revenues" in the following) and the comparison of results was performed.

The data collection concerned:

1. Experimental yields data (total yield and that of different types of cured products, as previously reported) at each locations for different $\mathrm{N}$ fertilization treatments;

2. Ordinary production (source: Producers Associations);

3. Information about tobacco farm structures at each location, obtained by means of direct questionnaires to farmers;

4. Information about both fertilizers and tobacco prices, collected through Producers Associations documents. In particular, tobacco prices were derived by delivery bulletins that contained detailed information with respect to each tobacco quality class.

The estimates of revenues relate to the composition of production by quality category. They were based on the sorting of cured leaves by farmers and on the assessment by experts (previously reported blind evaluation) before the previous reported training activity.

\section{Statistical analyses}

Yield and its components (number of leaves per plant and cured leaves mean weight), qualitative traits (total alkaloids, reducing sugars, chlorides, total Kjeldahl $\mathrm{N}, \mathrm{NH}_{4}-\mathrm{N}$, $\mathrm{NO}_{3}-\mathrm{N}, \mathrm{TSNA}$ ) and net revenues were subjected to analysis of variance (ANOVA) with $\mathrm{N}$ treatments combined over different locations (20) and means were separated with the least significant difference (LSD) at $\mathrm{P} \leq 0.05$ and $\mathrm{P} \leq 0.01$. Soil residual contents of mineral $\mathrm{N}\left(\mathrm{NO}_{3}-\mathrm{N}\right.$ and $\left.\mathrm{NH}_{4}-\mathrm{N}\right)$ were subjected to ANOVA following a split-plot scheme with sampling depth as main plot and $\mathrm{N}$ fertilization as subplot, combined over different locations. With regard to color measurements, the average values of the response to $\mathrm{N}$ fertilization were estimated by adjusting the data in a mixed model, considering $\mathrm{N}$ and leaf type as fixed factors and locations as a random factor, using the environment $\mathrm{R}$ (21) and extensions (ade4, lme4, ggplot2) (22).

\section{RESULTS AND DISCUSSION}

\section{Irrigation}

The seasonal irrigation volumes, based on effective water consumption estimated by crop evapotranspiration, ranged from 1640 (B3, crop duration of 97 days) to $3920 \mathrm{~m}^{3} \mathrm{ha}^{-1}$ (B11, crop duration of 142 days) across locations. However, the actual seasonal volumes, empirically determined by growers were generally lower (Table 2) than the estimated ones, presumably growers in the Benevento province tend to apply a deficit irrigation to obtain products with high nicotine content and better texture and flavor $(23,24)$. The empirically-defined irrigation watering volumes (Table 2) were frequently higher than those calculated by the irrigation scheduling over different locations (80 to $350 \mathrm{~m}^{3} \mathrm{ha}^{-1}$ ) and depended on plant growth stage, indicating that, on the whole, irrigation water was seldom applied efficiently by farmers. Similarly, the number of waterings by the empirical irrigation was always lower than that of the irrigation scheduling at different locations (3-7 vs. $7-10$ ). Both of these results demonstrate that the previously mentioned deficit irrigation to improve some quality aspects of cured products was generally applied by lengthening of the irrigation intervals (25).

\section{Plant growth, yield and quality, soil $N$ content}

Maximum plant dry matter was achieved with the N100 treatment at the B6 location and with the NFP at B4 and B10 locations (data not shown). There was no location where N200 was necessary to obtain maximum dry matter. These results demonstrate that a rate of approximately $120 \mathrm{~kg} \mathrm{~N} \mathrm{ha}^{-1}$ could be considered optimal to obtain maximum plant growth as was previously reported for Burley tobacco grown in similar pedoclimatic conditions (6).

The Specific Leaf Weight (SLW), measured at the beginning of rapid growth, was positively influenced by fertilization, as already reported for tobacco (26) and other species $(17,27,28)$, and increased up to NFP rate in 3 out of 4 locations (Figure 1). SLW has often been associated with leaf thickness and has been documented in previous studies $(25,28)$. An improving effect of potassium $(\mathrm{K})$ nutrition on this leaf characteristic was also well documented through its effect on leaf structure in tobacco $(26)$, bean $(29,31)$ and rice (32). Since in the present experiment increasing doses of $\mathrm{K}$ were applied with increasing $\mathrm{N}$ rates (Table 2), the effect of $\mathrm{K}$ could not be separated from that of $\mathrm{N}$ on this or others parameters. 


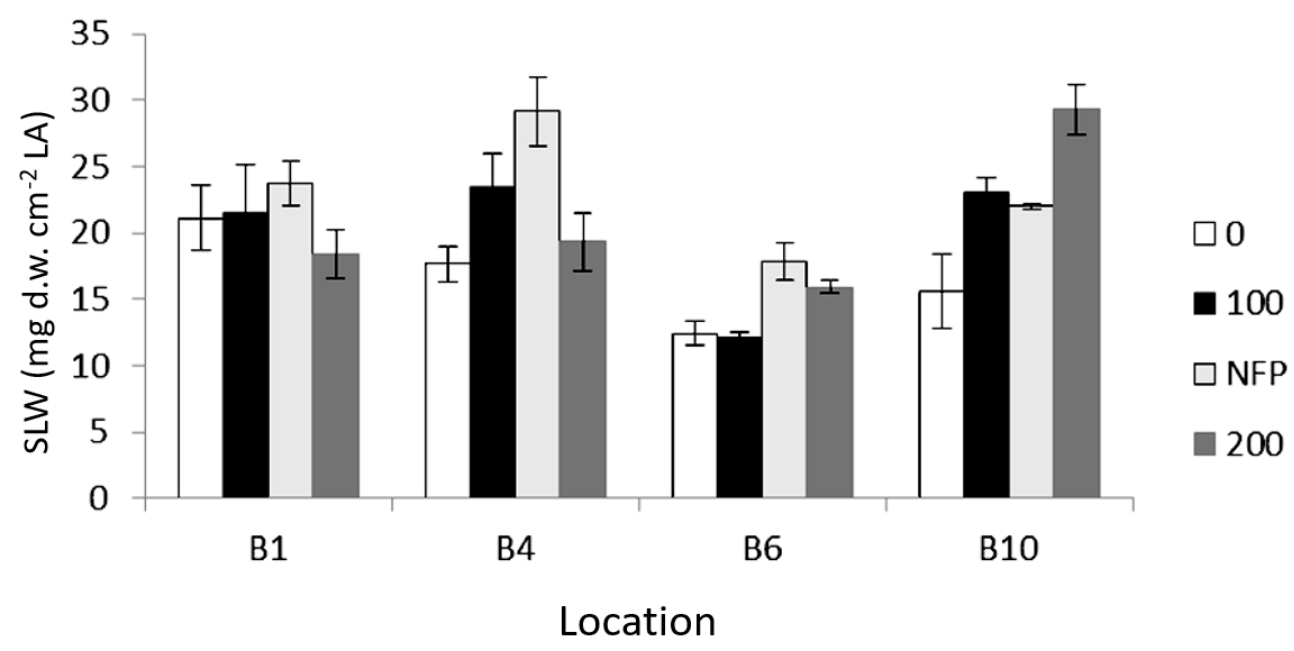

Figure 1. The effect of $\mathrm{N}$ fertilization treatments $\left(0,100\right.$ and $200 \mathrm{~kg} \mathrm{~N} \mathrm{ha}^{-1}$; NFP, $\mathrm{N}$ dose by $\mathrm{N}$ fertilization plan) on the Specific Leaf Weight (SLW, $\mathrm{mg} \mathrm{d.w.} \mathrm{cm}^{-2}$ leaf area, LA) measured at the beginning of rapid growth at different locations. Data are mean \pm standard error of three replicated blocks. B1, B4, B6 and B10 are location codes.

The total yield of cured leaf was significantly increased by fertilization up to the NFP treatment, but no significant further increase was measured for the N200 treatment (Table 3), in agreement to previous work on Burley tobacco $(6,16)$. Interestingly, similar trends in total yield were obtained at all locations (the interaction location $\times \mathrm{N}$ fertilization was not significant; Table 3 ). The significant differences in yields of cured leaves among locations (Table 3) were presumably due to some differences in soil conditions (Table 1), crop management (Table 2) and types of cured products (Table 3 ).

As for different commercial types of cured products, both $\mathrm{Fl}$ and $\mathrm{Fh}$ were measured at all locations while only at some locations there were wrappers (B1), Sl (B1, B4, and B9) or Sh (B1 and B4) commercial types (Table 3). As for wrappers at B1, they amounted to only $10 \%$ of total cured leaves (as averaged over fertilization treatments). Surprisingly, fertilization increased yield of wrappers up to the NFP treatment, which for that location was just $113.5 \mathrm{~kg} \mathrm{~N} \mathrm{ha}^{-1}$, without any significant increase at the N200 treatment (Table 3). These results are different from those for Cuban tobacco as reported by BORGES et al. (10) who found that a supply of $\mathrm{N}$ around $190 \mathrm{~kg} \mathrm{ha}^{-1}$ resulted in maximum high quality wrapper yield from the middle stalk position. In addition, in that study the wrapper production accounted for $75 \%$ of total production of this commercial type, much greater than that obtained at $200 \mathrm{~kg} \mathrm{~N} \mathrm{ha}^{-1}$ in the present experiment which was only $14 \%$, due to foliar diseases, mainly caused by infestations of tobacco flea beetle (Epitrix hirtipennis (Melsheimer)) very widespread in that area, or mechanical injuries.

Fl yield was extremely variable among locations and was positively influenced by fertilization up to N200 treatment (Table 3). For the Fh product, there was a significant location $\times \mathrm{N}$ fertilization interaction (Table 3) since Fh yield increased with fertilization in 9 out of 11 locations and the increments were significant up to $200 \mathrm{~kg} \mathrm{~N} \mathrm{ha}^{-1}$ in B1, B2, B6, B9 and B10, but only up to NFP treatment in B4, B5, B8 and B11 locations (Figure 2). These results were similar to those previously reported for Burley (6) and Cuban tobacco (10). Moreover, Fh yield did not change significantly with $\mathrm{N}$ treatments at $\mathrm{B} 3$ while it decreased with N200 treatment at B7 location (Figure 2).

Although yields of Fh generally increased with N (Table 3), the percentage of Fh on total yields did not vary with $\mathrm{N}$ treatment and was always slightly less than $50 \%$. However, there was large variability across locations, ranging from 27 (B1) to 64\% (B7), with differences that were likely due to differences in water regimes (Table 2). It is well known that high $\mathrm{N}$ rates can result in darker, thicker leaves $(13,33)$, especially if water is limited during leaf ripening since both leaf expansion and catabolic processes of nitrogen substances stored in the leaf (mainly chlorophyll and proteins) are reduced under those conditions (9). As a consequence, these substances do not move into the phloem for reallocation processes but accumulate in the leaf (34), producing heavier tissue $(9,35)$. The same can occur under irrigation conditions when plants showed a luxury consumption of $\mathrm{N}$ at a high rate of $\mathrm{N}$ fertilization and then the excess of $\mathrm{N}$, that was not remobilized, accumulated in the leaf tissues (36).

No effect of fertilization was recorded on yields of shredded tobacco (both light or heavy types) and significant changes due to different locations were recorded in the $\mathrm{Sl}$ type yield (Table 3 ).

On average, heavy filler products showed, as expected, a higher leaf mean weight than light filler ones (Table 3 ). It is well known that high leaf weight means a cured leaf with both increased thickness and density which indicates leaves with an considerable body $(9,26,37)$. As previously reported, the body of a leaf is one of the main characteristics that determine the commercial quality of tobacco $(5,9$, 37 ). Based on the leaf mean weight, in 7 out of 11 locations cured leaves appeared to be correctly sorted by farmers to heavy and light categories of filler type (Table 3). In fact, there were only two cases of wrong attribution of $\mathrm{Fh}$ to $\mathrm{Fl}$ type (B2 and B6; Table 3) as well as only two cases of F1 wrongly attributed to Fh type (B1 and B4; Table 3). 
Table 3. The effect of location and $\mathbf{N}$ fertilization $\left(0,100\right.$ and $200 \mathrm{~kg} \mathrm{~N} \mathrm{ha}^{-1}$; $\mathbf{N F P}, \mathbf{N}$ dose by $\mathbf{N}$ fertilization plan) on yield at $19 \%$ standard moisture and mean leaf weight of cured tobacco leaves (Kentucky type) at final harvest. Total yields (given in megagrams per hectare) and those of different types of product are reported (cigar wrappers, cigar heavy and light fillers, Fh and Fl; cigar heavy and light shredded type, Sh and SI). The analysis of variance (ANOVA) reports the significance of treatments and their interaction. Small letters indicate least significant differences at $\mathrm{P}<0.05$ whereas capital letters indicate least significant differences at $\mathrm{P}<0.01$. B1, B2, B3, B4, B5, B6, B7, $\mathrm{B} 8, \mathrm{~B} 9, \mathrm{~B} 10$ and B11 are location codes.

\begin{tabular}{|c|c|c|c|c|c|c|c|c|}
\hline & $\begin{array}{c}\text { Total } \\
\text { yield } \\
\left(\mathrm{Mg} \mathrm{ha}^{-1}\right)\end{array}$ & $\begin{array}{c}\text { Cigar wrappers } \\
\text { yield } \\
\left.\text { (Mg ha }^{-1}\right)\end{array}$ & $\begin{array}{c}\mathrm{Fl} \\
\text { yield } \\
\left(\mathrm{Mg} \mathrm{ha}^{-1}\right)\end{array}$ & $\begin{array}{c}\text { Fh } \\
\text { yield } \\
\left(\mathrm{Mg} \mathrm{ha}^{-1}\right)\end{array}$ & $\begin{array}{c}\text { SI } \\
\text { yield } \\
\left(\mathrm{Mg} \mathrm{ha}^{-1}\right)\end{array}$ & $\begin{array}{c}\text { Sh } \\
\text { yield } \\
\left(\mathrm{Mg} \mathrm{ha}^{-1}\right)\end{array}$ & $\begin{array}{c}\text { Fl leaf } \\
\text { mean weight } \\
\text { (g) }\end{array}$ & $\begin{array}{c}\text { Fh leaf } \\
\text { mean weight } \\
\text { (g) }\end{array}$ \\
\hline \multicolumn{9}{|c|}{ Location (L) } \\
\hline B1 & 2.352 CD & 0.214 & $0.903 \mathrm{~B}$ & $0.644 \mathrm{~A}$ & $0.391 \mathrm{~b}$ & 0.187 & $32.9 \mathrm{D}$ & $32.6 \mathrm{D}$ \\
\hline B2 & $0.922 \mathrm{~A}$ & - & $0.446 \mathrm{~A}$ & $0.475 \mathrm{~A}$ & - & - & $18.4 \mathrm{AB}$ & $21.3 \mathrm{~B}$ \\
\hline B3 & $3.778 \mathrm{E}$ & - & $1.456 \mathrm{C}$ & $2.322 \mathrm{D}$ & - & - & $20.1 \mathrm{~B}$ & $32.5 \mathrm{D}$ \\
\hline B4 & $2.866 \mathrm{D}$ & - & $1.349 \mathrm{C}$ & $0.990 \mathrm{~B}$ & $0.261 \mathrm{a}$ & 0.110 & $25.8 \mathrm{C}$ & $34.0 \mathrm{D}$ \\
\hline B5 & $2.718 \mathrm{D}$ & - & 1.195 BC & $1.523 \mathrm{C}$ & - & - & $19.8 B$ & $34.1 \mathrm{D}$ \\
\hline B6 & 2.104 CD & - & $0.835 \mathrm{~B}$ & $0.593 \mathrm{~A}$ & - & - & $14.8 \mathrm{~A}$ & $17.0 \mathrm{~A}$ \\
\hline B7 & $2.477 \mathrm{D}$ & - & $0.860 \mathrm{~B}$ & $1.615 \mathrm{C}$ & - & - & $19.5 \mathrm{~B}$ & $24.4 \mathrm{~B}$ \\
\hline B8 & $1.837 \mathrm{BC}$ & - & $0.849 \mathrm{~B}$ & $0.988 \mathrm{~B}$ & - & - & - & - \\
\hline B9 & $1.959 \mathrm{C}$ & - & $0.646 \mathrm{AB}$ & $0.889 \mathrm{~B}$ & $0.279 \mathrm{a}$ & - & 17.6 AB & $28.2 \mathrm{C}$ \\
\hline B10 & 2.204 CD & - & 1.044 BC & $1.077 \mathrm{~B}$ & - & - & - & - \\
\hline B11 & $1.437 \mathrm{~B}$ & - & $0.413 \mathrm{~A}$ & $0.701 \mathrm{AB}$ & - & - & - & - \\
\hline \multicolumn{9}{|c|}{$N$ fertilization $(N)$} \\
\hline 0 & $1.699 \mathrm{~A}$ & $0.000 \mathrm{a}$ & $0.694 \mathrm{~A}$ & $0.812 \mathrm{~A}$ & 0.300 & 0.206 & $18.2 \mathrm{~A}$ & $26.1 \mathrm{~A}$ \\
\hline 100 & $2.186 \mathrm{~B}$ & $0.156 \mathrm{~b}$ & $0.877 \mathrm{~B}$ & $1.053 \mathrm{~B}$ & 0.319 & 0.242 & $21.2 \mathrm{~B}$ & $27.3 \mathrm{AB}$ \\
\hline NFP & $2.443 \mathrm{BC}$ & $0.328 \mathrm{c}$ & $0.950 \mathrm{~B}$ & $1.205 \mathrm{C}$ & 0.386 & 0.066 & $22.8 \mathrm{~B}$ & $28.5 \mathrm{~B}$ \\
\hline 200 & $2.638 \mathrm{C}$ & $0.372 \mathrm{c}$ & $1.114 \mathrm{C}$ & $1.227 \mathrm{C}$ & 0.236 & 0.078 & $21.1 \mathrm{~B}$ & $30.7 \mathrm{C}$ \\
\hline \multicolumn{9}{|c|}{ ANOVA } \\
\hline L & ** & - & $* *$ & $* *$ & * & NS & ** & ** \\
\hline $\mathrm{N}$ & ** & * & * & ** & * & NS & $* *$ & $* *$ \\
\hline $\mathrm{L} \times \mathrm{N}$ & NS & - & NS & * & NS & NS & NS & NS \\
\hline
\end{tabular}

* $\quad$ significant at $\mathrm{P}<0.05$

** significant at $\mathrm{P}<0.01$

NS not significant

- not determined

Fh and FI: heavy and light filler, respectively; Sh and SI: heavy and light shredded type, respectively

Total alkaloids and chlorides of Fh products significantly increased and decreased, respectively, with increasing fertilization up to $100 \mathrm{~kg} \mathrm{~N}^{-1}$ (total alkaloids) and NFP (chlorides; Table 4) treatment $(6,16,26)$. Location $\times \mathrm{N}$ fertilization interaction was significant for the content of reducing sugars and total $\mathrm{N}$ (Figure $3 \mathrm{a}, \mathrm{b}$ ), $\mathrm{NH}_{4}-\mathrm{N}, \mathrm{NO}_{3}-\mathrm{N}$ and TSNA (Table 4 and Figure 4). In particular, the reducing sugars generally decreased with fertilization in all locations with the exception of B6 (Figure 3a). By contrast, the total $\mathrm{N}$ concentration (Figure $3 \mathrm{~b}$ ), the content of $\mathrm{NH}_{4}-\mathrm{N}$, $\mathrm{NO}_{3}-\mathrm{N}$ and TSNA (Figure 4) generally rose with increasing $\mathrm{N}(6,13,26)$ but not equally in all locations. Differences between locations, regardless of $\mathrm{N}$ amounts, were probably due to different irrigation regimes applied at different experimental sites (Table 2) which presumably interacted with fertilization, thus modulating the $\mathrm{N}$ uptake from the soil, its accumulation in plants in different forms (organic or mineral) and its mobilization within them $(16,36)$. Moreover, since average values of $\mathrm{NH}_{4}-\mathrm{N}, \mathrm{NO}_{3}-\mathrm{N}$ and TSNA changed markedly among locations, it is likely that differences among curing conditions (leaf arrangement within the curing barn, duration of different thermal regimes etc.) might also have contributed to these discrepancies in the chemistry of cured leaves.

The $\mathrm{NO}_{3}-\mathrm{N}$ content of $\mathrm{Fl}$ cured product did not vary significantly with fertilization and it was significantly higher in B1 than in B4, B6 and B10 locations (Table 4). There was a significant interaction location $\times \mathrm{N}$ fertilization for total $\mathrm{N}$ of the Fl leaves (Table 4, Figure 3c): in particular, it rose as fertilization increased in different locations, e.g., B1, B4, and B6 but not in B10 (Figure 3c) $(6,26)$.

Total $\mathrm{N}$ of commercial products categorized as $\mathrm{Fh}$ and $\mathrm{Fl}$ at each locations was, on average, equal to 3.75 and $3.05 \%$, respectively (Table 4), thus showing that also in this case those cured products were properly allocated by farmers to the categories Fh and Fl. Accumulation of $\mathrm{N}$ in the leaf tissue in organic form also contributed markedly to the body of the same leaves, as previously reported $(9,37)$. As for the color of cured leaves, the CIE Lab parameters L, $\mathrm{C}, \mathrm{H}$ and the summary index of color quality of products were different between $\mathrm{Fl}$ and $\mathrm{Fh}$. They were considerably affected by location but only minimally by fertilization, respectively (Figure 5). In particular, $\mathrm{L}$ and $\mathrm{C}$ of the heavy leaves (Fh; Figure 5) were less than those of light ones (Fl), thus showing a dark brown color, less bright and more opaque than $\mathrm{Fl}$ according to that reported by ASCIONE et al. (26). Nitrogen fertilization hardly increased $\mathrm{L}$ and $\mathrm{C}$ of $\mathrm{Fl}$ leaves (Figure 5), thus they appeared light but brilliant brown in color. On the whole, the quality of color appeared higher in heavy than in light leaves (Figure 5).

As for the effect of location where samples were collected, $\mathrm{L}$ and $\mathrm{C}$ were much higher at $\mathrm{B} 8$ as compared to the other 5 locations (B1, B2, B3, B6 and B10; Figure 5). Differences between locations could be attributed to differences in water regimes and leaf curing, both very important factors to define the final color of cured leaves. These differences, 


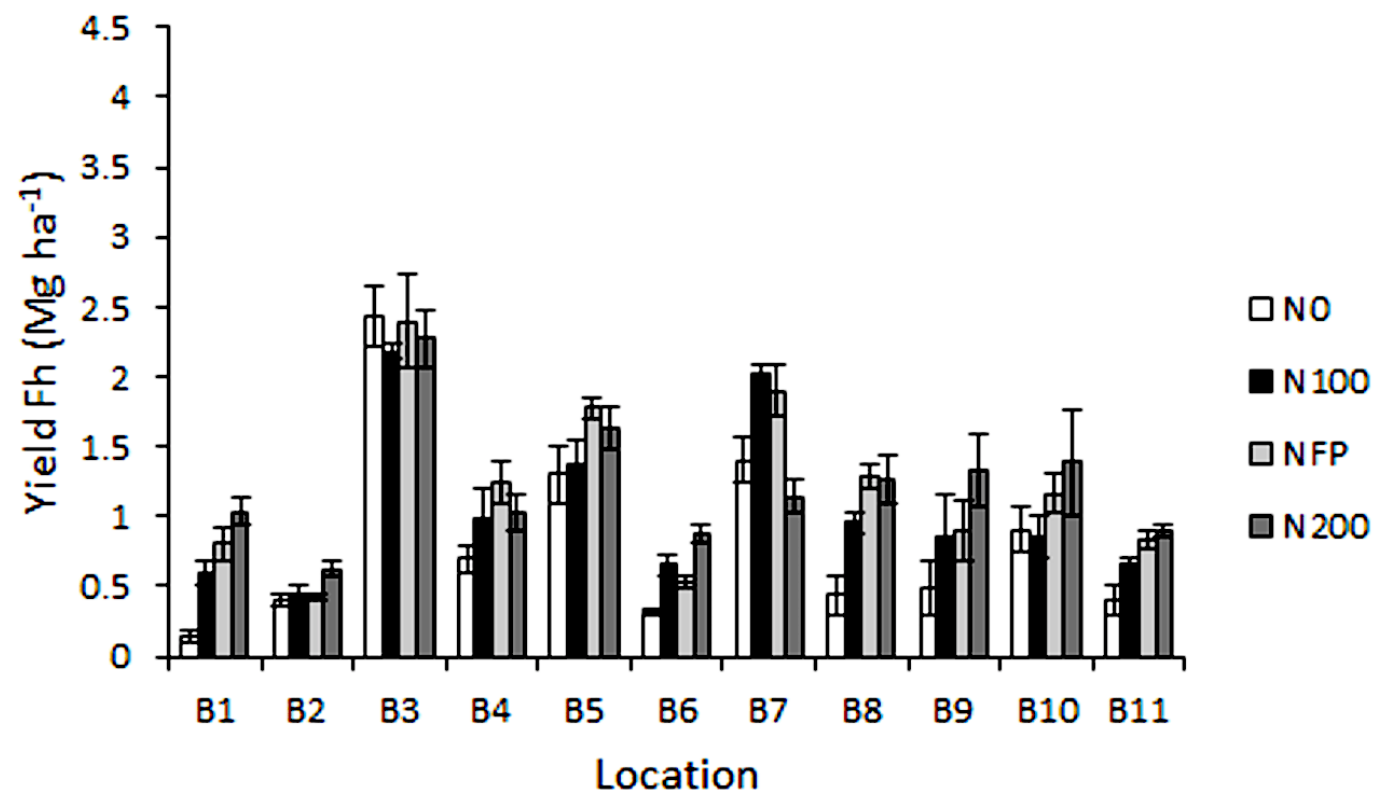

Figure 2. The effect of $\mathrm{N}$ fertilization treatments $\left(0,100\right.$ and $200 \mathrm{~kg} \mathrm{~N} \mathrm{ha}^{-1} ; \mathrm{NFP}, \mathrm{N}$ dose by $\mathrm{N}$ fertilization plan) on yields of heavy filler leaves (Fh) at different locations. Data are mean \pm standard error of three replicated blocks. B1, B2, B3, B4, B5, B6, B7, B8, B9, B10 and B11 are location codes.

Table 4. The effect of location and $\mathbf{N}$ fertilization $\left(0,100\right.$ and $200 \mathrm{~kg} \mathrm{~N} \mathrm{ha}^{-1}$; NFP, $N$ dose by $\mathbf{N}$ fertilization plan) on the leaf content of total alkaloids, reducing sugars, chlorides, $\mathrm{NH}_{4}-\mathrm{N}, \mathrm{NO}_{3}-\mathrm{N}$, total $\mathrm{N}$ and tobacco specific nitrosamines (TSNA) of Fh cured products, and $\mathrm{NO}_{3}-\mathrm{N}$ and total $\mathrm{N}$ of $\mathrm{FI}$ cured products. The analysis of variance (ANOVA) reports the significance of treatments and their interaction. Small letters indicate least significant differences at $P<0.05$ whereas capital letters indicate least significant differences at $P<0.01$. B1, B2, B3, B4, B5, B6, B7, B8, B9, B10 and B11 are location codes.

\begin{tabular}{|c|c|c|c|c|c|c|c|c|c|}
\hline & \multicolumn{7}{|c|}{$\mathrm{Fh}$} & \multicolumn{2}{|c|}{$\mathrm{FI}$} \\
\hline & $\begin{array}{c}\text { Total } \\
\text { alkaloids } \\
\text { (\% d.w.) }\end{array}$ & $\begin{array}{l}\text { Reducing } \\
\text { sugars } \\
\text { (\% d.w.) }\end{array}$ & $\begin{array}{l}\text { Chlorides } \\
\text { (\% d.w.) }\end{array}$ & $\begin{array}{l}\mathrm{NH}_{4}-\mathrm{N} \\
\text { (\% d.w.) }\end{array}$ & $\begin{array}{l}\mathrm{NO}_{3}-\mathrm{N} \\
\text { (\% d.w.) }\end{array}$ & $\begin{array}{l}\text { Total N } \\
\text { (\% d.w.) }\end{array}$ & $\begin{array}{c}\text { TSNA } \\
\left(\mathrm{mg} \mathrm{kg}^{-1} \text { d.w. }\right)\end{array}$ & $\begin{array}{l}\mathrm{NO}_{3}-\mathrm{N} \\
\text { (\% d.w.) }\end{array}$ & $\begin{array}{l}\text { Total N } \\
\text { (\% d.w.) }\end{array}$ \\
\hline \multicolumn{10}{|c|}{ Location (L) } \\
\hline B1 & $2.9 \mathrm{~b}$ & 50 & $1.7 \mathrm{~A}$ & $0.13 \mathrm{~A}$ & $0.06 \mathrm{~A}$ & $2.6 \mathrm{~A}$ & $8.2 \mathrm{a}$ & $0.28 \mathrm{~b}$ & $3.4 \mathrm{~b}$ \\
\hline B4 & $2.3 \mathrm{a}$ & 47 & $2.6 \mathrm{C}$ & $0.39 \mathrm{C}$ & $0.22 \mathrm{~B}$ & $4.5 \mathrm{C}$ & $7.7 \mathrm{a}$ & $0.14 \mathrm{a}$ & $3.1 \mathrm{~b}$ \\
\hline B6 & $2.8 \mathrm{~b}$ & 32 & $1.5 \mathrm{~A}$ & $0.33 \mathrm{BC}$ & $0.19 \mathrm{~B}$ & $4.3 \mathrm{BC}$ & $10.4 a b$ & $0.14 \mathrm{a}$ & $2.8 \mathrm{a}$ \\
\hline B10 & $2.7 \mathrm{~b}$ & 37 & $2.0 \mathrm{~B}$ & $0.27 \mathrm{~B}$ & $0.05 \mathrm{~A}$ & $3.5 \mathrm{AB}$ & $15.0 \mathrm{~b}$ & $0.18 \mathrm{a}$ & $2.9 \mathrm{a}$ \\
\hline \multicolumn{10}{|c|}{$N$ fertilization $(N)$} \\
\hline 0 & $2.2 \mathrm{a}$ & $5.1 \mathrm{~B}$ & $2.0 \mathrm{bc}$ & $0.20 \mathrm{~A}$ & $0.08 \mathrm{~A}$ & $3.6 \mathrm{AB}$ & $5.9 \mathrm{~A}$ & 0.14 & $2.7 \mathrm{~A}$ \\
\hline 100 & $2.7 \mathrm{~b}$ & $4.4 \mathrm{~B}$ & $2.1 \mathrm{c}$ & $0.27 \mathrm{~B}$ & $0.09 \mathrm{~A}$ & $4.0 \mathrm{~B}$ & $8.2 \mathrm{AB}$ & 0.17 & $2.9 \mathrm{~B}$ \\
\hline NFP & $2.7 \mathrm{~b}$ & $4.6 \mathrm{~B}$ & $1.9 a b$ & $0.26 \mathrm{~B}$ & $0.11 \mathrm{~A}$ & $3.5 \mathrm{~A}$ & $12.9 \mathrm{BC}$ & 0.20 & $3.0 \mathrm{~B}$ \\
\hline 200 & $3.0 \mathrm{~b}$ & $2.5 \mathrm{~A}$ & $1.8 \mathrm{a}$ & $0.39 \mathrm{C}$ & $0.24 \mathrm{~B}$ & $3.9 \mathrm{~B}$ & $14.3 \mathrm{C}$ & 0.23 & $3.6 \mathrm{C}$ \\
\hline \multicolumn{10}{|c|}{ ANOVA } \\
\hline$L$ & * & NS & ** & $* *$ & $* *$ & $* *$ & * & * & * \\
\hline $\mathrm{N}$ & * & $* *$ & * & ** & ** & * & $* *$ & NS & $* *$ \\
\hline$L \times N$ & NS & ** & NS & ** & $* *$ & ** & * & NS & $* *$ \\
\hline
\end{tabular}

* $\quad$ significant at $\mathrm{P}<0.05$

** $\quad$ significant at $P<0.01$

NS not significant

d.w. dry weight

Fh and FI: heavy and light filler, respectively 

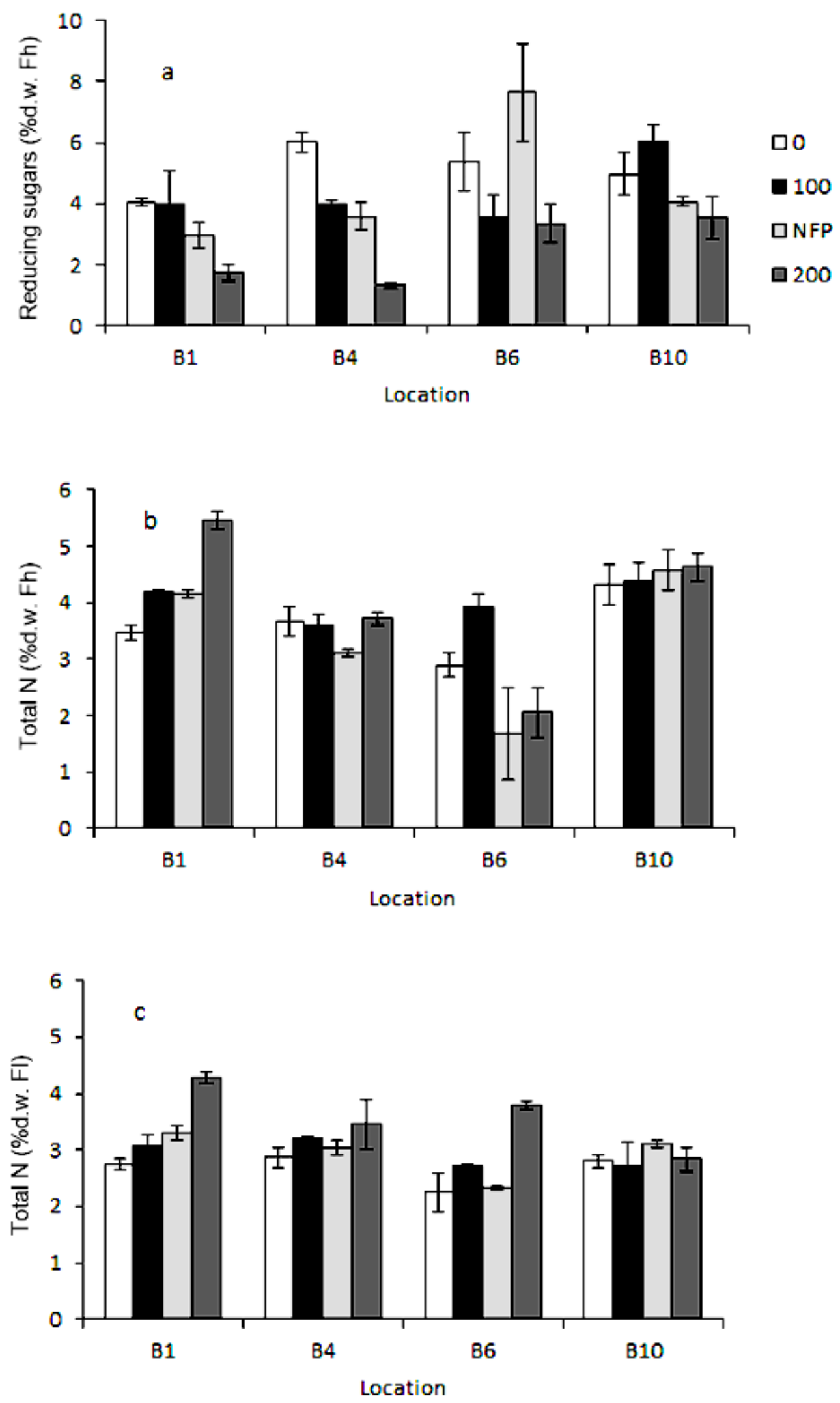

Figure 3. The effect of $\mathbf{N}$ fertilization treatments $\left(0,100\right.$ and $200 \mathrm{~kg} \mathrm{~N}^{\mathrm{N}} \mathrm{h}^{-1}$; $\mathrm{NFP}, \mathrm{N}$ dose by $\mathrm{N}$ fertilization plan) on reducing sugars (a) and total $\mathbf{N}$ contents of heavy (Fh; b) and light filler products (FI; c) at different locations. Data are mean \pm standard error of three replicated blocks. B1, B4, B6 and B10 are location codes. 

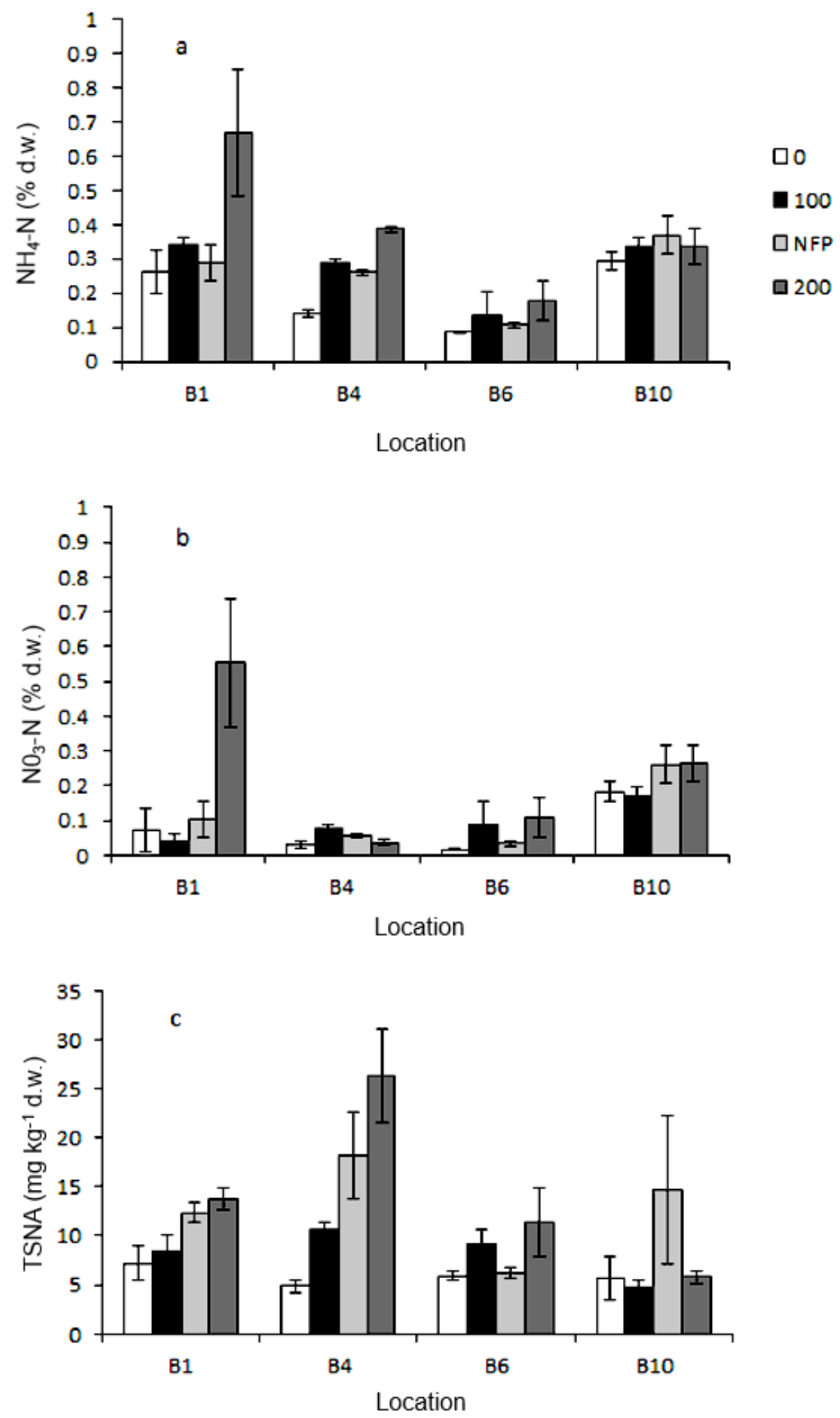

Figure 4. The effect of $\mathrm{N}$ fertilization treatments $\left(0,100\right.$ and $200 \mathrm{~kg} \mathrm{~N}^{-1} ; \mathrm{NFP}, \mathrm{N}$ dose by $\mathrm{N}$ fertilization plan) on $\mathrm{NH}_{4}-\mathrm{N}(\mathrm{a}), \mathrm{NO}_{3}-\mathrm{N}$ (b), tobacco specific nitrosamines (TSNA; c) contents of heavy filler products (Fh) at different locations. Data are mean \pm standard error of three replicated blocks. B1, B4, B6 and B10 are location codes. 

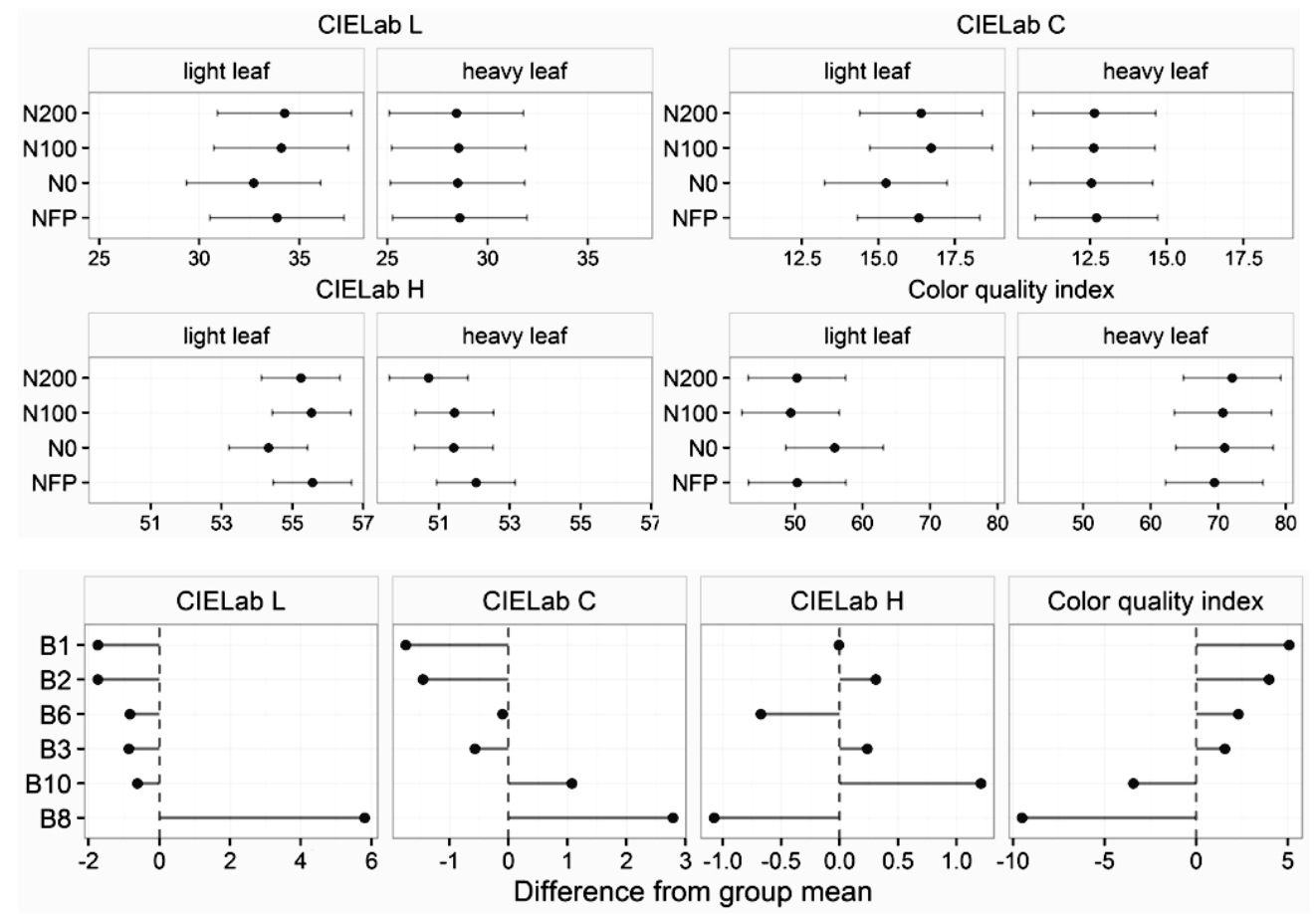

Figure 5. The effect of $\mathrm{N}$ fertilization treatments $\left(0,100\right.$ and $200 \mathrm{~kg} \mathrm{~N} \mathrm{ha}^{-1}$; NFP, $\mathrm{N}$ dose by $\mathrm{N}$ fertilization plan) or locations on color parameters (L, H, C and color quality index) of heavy and light leaves. Horizontal bars indicate confidence intervals at $95 \%$. B1. B2, B3, $\mathrm{B} 6, \mathrm{~B} 8$ and B10 are location codes.

in spite of fertilization treatments or other cultivation practices, were not uncommon among different locations. As previously reported for leaf mean weight and total $\mathrm{N}$ content, the products which had been cured on the basis of their color seemed to get properly allocated to the categories Fh and Fl by farmers.

Finally, with regard to residual content of mineral $\mathrm{N}$ at the end of cropping in the soil layers was between 0 and $0.6 \mathrm{~m}$, the nitrate quota increased significantly with application only in plots fertilized with $200 \mathrm{~kg} \mathrm{~N} \mathrm{ha}^{-1}$ (Table 5), a $72 \%$ increase above the $\mathrm{N} 0$ treatment. In addition, corresponding values at N0, N100 and NFP plots (Table 5) were not different from $57.3 \mathrm{~kg} \mathrm{~N} \mathrm{ha}^{-1}$ measured in all plots before application at the beginning of cropping in the soil profile 0-0.3 m (Table 5).

Residual soil mineral $\mathrm{N}$ (both $\mathrm{NO}_{3}-\mathrm{N}$ and $\mathrm{NH}_{4}-\mathrm{N}$ ) content varied considerably in different locations with fertilization treatments and, as expected, the nitrate quota changed between depths (data not shown). These differences appear attributable to different types of soil, initial soil fertility and irrigation regimes among locations. In addition, the particular rainfall regimes of July and August may have determined more or less intense leaching phenomena of nitrate quota along the soil profile $0-0.6 \mathrm{~m}$, or below it, at the different locations.

\section{Economic results}

The economic effects of different fertilization treatments were estimated by assessing the fertilization costs and the monetary value of product obtained under each experimen- tal condition (fertilization and location; Table 6).

Average costs of fertilization differed among locations due to different commercial products applied and, as expected, they rose with increasing fertilization rates (Table 6). Different net revenues were the result of both the average yields (obtained at each location with different fertilization protocols) and the yield composition by different quality categories which affected product average prices (2). In the present experiment these varied between 5.90 (wrapper) and 0.75 (light shredded) $€ \mathrm{~kg}^{-1}$ (2). According to agronomic aspects, there was a high variability of economic results among different locations that was mainly due to differences in crop management, as well as yield and quality categories. As for net revenues, location B3 showed an above-average performance for all fertilization treatments due to the good sorting effected by the growers for cured leaves of both heavy and light filler quality (properly sorted samples accounted for about $75 \%$ of the total yield (2), which consequently commanded prices twofold higher than those of cured leaves of the same kind of quality but badly sorted (2). In addition, both B1 and B3 had very special attention to harvesting and subsequent leaf piercing and threading, always carried out manually to reduce the incidence of leaf breakage. This attention could also explain their good economic performance.

Locations B5 and B7 obtained better economic results at N0, N100 and NFP treatments (Table 6).

There was a significant location $\times \mathrm{N}$ fertilization interaction for net revenues $\left(\mathrm{P}<0.001 ; \mathrm{LSD}_{\mathrm{int}}=1754.14 € \mathrm{ha}^{-1}\right.$; Table 6). In particular, net revenues increased with fertilization up to 100 (B7) and NFP at B4, B5 and B8, 
Table 5. The effect of soil depth, location and $\mathbf{N}$ fertilization $\left(0,100\right.$ and $200 \mathrm{~kg} \mathrm{~N}^{\mathrm{N}} \mathrm{ha}^{-1}$; $\mathrm{NFP}, \mathrm{N}$ dose by $\mathbf{N}$ fertilization plan) on the soil content of mineral $\mathrm{N}\left(\mathrm{NO}_{3}-\mathrm{N}\right.$ and $\left.\mathrm{NH}_{4}-\mathrm{N}\right)$ before transplanting (before $\mathrm{N}$ fertilization treatments) and after final harvest. The analysis of variance (ANOVA) reports the significance of treatments and their interaction. Small letters indicate least significant differences at $P<0.05$ whereas capital letters indicate least significant differences at P<0.01. B1, B2, B3, B4, B5, B6, B7, B8, B9, B10 and B11 are location codes.

\begin{tabular}{|c|c|c|c|c|}
\hline & \multicolumn{2}{|c|}{ Before transplanting } & \multicolumn{2}{|c|}{ After final harvest } \\
\hline & $\mathrm{NO}_{3}-\mathrm{N}\left(\mathrm{kg} \mathrm{ha}^{-1}\right)$ & $\mathrm{NH}_{4}-\mathrm{N}\left(\mathrm{kg} \mathrm{ha}^{-1}\right)$ & $\mathrm{NO}_{3}-\mathrm{N}\left(\mathrm{kg} \mathrm{ha}^{-1}\right)$ & $\mathrm{NH}_{4}-\mathrm{N}\left(\mathrm{kg} \mathrm{ha}^{-1}\right)$ \\
\hline \multicolumn{5}{|c|}{ Soil depth (SD) } \\
\hline $0-0.30 \mathrm{~m}$ & 57.3 & 68.1 & $74.6 \mathrm{~B}$ & 29.3 \\
\hline $0.30-0.60 \mathrm{~m}$ & - & - & $54.6 \mathrm{~A}$ & 31.1 \\
\hline \multicolumn{5}{|l|}{ Location (L) } \\
\hline B1 & $60.3 \mathrm{~B}$ & $54.5 \mathrm{~B}$ & $90.8 \mathrm{DE}$ & $31.8 \mathrm{BC}$ \\
\hline B2 & $33.1 \mathrm{~A}$ & $82.8 \mathrm{D}$ & $84.4 \mathrm{D}$ & $39.1 \mathrm{CD}$ \\
\hline B3 & $37.3 \mathrm{AB}$ & $59.3 \mathrm{~B}$ & $58.7 \mathrm{C}$ & $48.6 \mathrm{D}$ \\
\hline B4 & $36.9 \mathrm{~A}$ & $63.4 \mathrm{~B}$ & $68.6 \mathrm{C}$ & $19.4 \mathrm{~A}$ \\
\hline B5 & $84.2 \mathrm{D}$ & $77.3 \mathrm{C}$ & $53.6 \mathrm{BC}$ & $29.0 \mathrm{~B}$ \\
\hline B6 & $38.5 \mathrm{~A}$ & $62.5 \mathrm{~B}$ & $31.9 \mathrm{~A}$ & $21.3 \mathrm{AB}$ \\
\hline B7 & $57.2 \mathrm{~B}$ & $77.2 \mathrm{CD}$ & 115.3 E & $18.6 \mathrm{~A}$ \\
\hline B8 & $54.3 \mathrm{~B}$ & $84.4 \mathrm{D}$ & $64.4 \mathrm{C}$ & $30.0 \mathrm{BC}$ \\
\hline B9 & $72.3 \mathrm{C}$ & $82.6 \mathrm{D}$ & $37.2 \mathrm{AB}$ & $28.8 \mathrm{~B}$ \\
\hline B10 & $80.0 \mathrm{CD}$ & $62.1 \mathrm{~B}$ & $69.2 \mathrm{CD}$ & $39.7 \mathrm{C}$ \\
\hline B11 & $76.7 \mathrm{C}$ & $42.9 \mathrm{~A}$ & $36.7 \mathrm{~A}$ & $26.2 \mathrm{AB}$ \\
\hline \multicolumn{5}{|c|}{$N$ fertilization $(N)$} \\
\hline 0 & - & - & $52.9 \mathrm{~A}$ & $35.7 \mathrm{~B}$ \\
\hline 100 & - & - & $56.0 \mathrm{~A}$ & $34.3 \mathrm{~B}$ \\
\hline NFP & - & - & $58.5 \mathrm{~A}$ & $26.0 \mathrm{~A}$ \\
\hline 200 & - & - & $91.1 \mathrm{~B}$ & $24.9 \mathrm{~A}$ \\
\hline \multicolumn{5}{|l|}{ ANOVA } \\
\hline SD & - & - & ** & NS \\
\hline L & $* *$ & $* *$ & ** & $* *$ \\
\hline$S D \times L$ & - & - & $* *$ & NS \\
\hline$N$ & - & - & $* *$ & $* *$ \\
\hline$S D \times N$ & - & - & NS & NS \\
\hline$L \times N$ & - & - & * & $* *$ \\
\hline$S D \times L \times N$ & - & - & NS & NS \\
\hline
\end{tabular}

* $\quad$ significant at $P<0.05$

** significant at $\mathrm{P}<0.01$

NS not significant

d.w. dry weight

- not determined

without any further increase at N200 treatment. The greatest overall increase in net revenues due to fertilization occurred at the B1 location and was mainly due to the higher yield of wrapper leaves which impacted revenues more than yields $(+30$ and $+10 \%$, respectively; Tables 6 and 3 ).

At B1, B2, B6, B9, B10, and B11 locations net revenues changed significantly only with application of maximum $\mathrm{N}$ rate (N200; Table 6) but the indirect negative economic impact of excessive $\mathrm{N}$ rate, as we report below, should also be considered (https://ec.europa.eu/agri culture/envir/measures_it).

On the whole the economic performance was the result of three factors: the relative change in revenues and costs, the average level of revenues related to crop management and product quality composition, and the weight of fertilization costs with respect to revenues. Generally, N rates affected costs more than revenues. As for expert evaluation results, differences were found between samples assorted before and after training activity carried out to improve samples homogeneity and all detected changes appeared favorable to obtain higher selling prices (2). In particular, regardless of location or fertilization treatments, the amount of total filler product, of both heavy and light types, increased in the post-training assortment with respect to the pre-training one $(+48 \%)(2)$. This result was generally due to the initial underestimation of several heavy and light filler samples, which, in all locations farmers labelled as shredded types, without any differences between $\mathrm{N}$ rates.

These results showed that tobacco growers could achieve more homogeneous samples with the same amount of cured product by simply using a more sophisticated sorting method, thus obtaining an enhanced commercial quality and, consequently, a better potential economic return by industrial buyers (2). Finally, better attention to harvesting and to leaf handling, in order to reduce the leaf breakage, should be recommended to growers. 
Table 6. The effect of location and $\mathbf{N}$ fertilization $\left(0,100\right.$ and $200 \mathrm{~kg} \mathrm{~N}^{\mathrm{N}} \mathrm{ha}^{-1}$; NFP, $\mathbf{N}$ dose by $\mathbf{N}$ fertilization plan) on fertilization costs and estimated revenues ( $€$ per hectare). Small letters indicate least significant differences (LSD) at $P<0.01$. LSD location $\times N$ fertilization at $\mathrm{P} \leq 0.01$ for estimated revenues is $1754.14 € \mathrm{ha}^{-1}$. B1, B2, B3, B4, B5, B6, B7, B8, B9, B10 and B11 are location codes.

\begin{tabular}{|c|c|c|c|c|c|c|c|}
\hline \multirow{2}{*}{ Location } & \multicolumn{3}{|c|}{ Fertilization costs $\left(€ \mathrm{ha}^{-1}\right)$} & \multicolumn{4}{|c|}{ Estimated revenues, net of fertilization costs $\left(€ \mathrm{ha}^{-1}\right)$} \\
\hline & N100 & NFP & N200 & No & N100 & NFP & N200 \\
\hline B1 & 408.04 & 523.43 & 740.40 & 1615.87 & 3792.32 & 5378.72 & 6105.29 \\
\hline B2 & 437.19 & 607.05 & 874.38 & 1644.93 & 1380.70 & 1029.13 & 1544.47 \\
\hline B3 & 491.36 & 652.74 & 982.71 & 8354.50 & 7583.19 & 7970.30 & 7524.03 \\
\hline B4 & 432.05 & 654.85 & 798.35 & 3910.88 & 4412.25 & 4540.75 & 4027.55 \\
\hline B5 & 345.64 & 341.51 & 626.64 & 4591.47 & 5042.42 & 6286.03 & 5822.05 \\
\hline B6 & 345.64 & 341.51 & 626.64 & 1492.82 & 2211.86 & 2412.96 & 3154.85 \\
\hline B7 & 345.64 & 341.51 & 626.64 & 5060.58 & 6386.38 & 6165.28 & 3751.00 \\
\hline B8 & 341.50 & 405.52 & 612.58 & 1907.56 & 3414.77 & 4411.32 & 4182.88 \\
\hline B9 & 324.10 & 393.92 & 612.58 & 2221.95 & 3218.64 & 3363.04 & 3934.66 \\
\hline B10 & 339.61 & 402.77 & 612.58 & 3301.48 & 3185.41 & 4125.60 & 5212.16 \\
\hline B11 & 331.97 & 419.38 & 601.41 & 1532.54 & 1887.40 & 2428.01 & 2821.04 \\
\hline Mean & 376.61 & 462.20 & 701.36 & $3239.50 \mathrm{~b}$ & $3864.67 \mathrm{ab}$ & $4373.74 \mathrm{a}$ & $4370.91 \mathrm{a}$ \\
\hline
\end{tabular}

\section{CONCLUSIONS}

Despite variability across locations, this area-wide investigation allowed us to reach a number of conclusions. Results demonstrated that the NFP level of fertilization achieved the best response in terms of yield and quality, while the rate of $200 \mathrm{~kg} \mathrm{~N} \mathrm{ha}^{-1}$ was often excessive since it did not produce, in most of the analyzed cases, any improvement in the Benevento province. The agronomic results also provided an interesting indication of the reliability of the correct allocation of cured products into different quality categories before selling. In many locations, the cured leaves' mean weight, leaves concentration of $\mathrm{N}$ compounds, or color seemed to confirm the importance of the separation between heavy and light products by growers. In particular, mean weight and total nitrogen concentrations were, as expected, higher in heavy products compared to light ones, and the color appeared darker and less bright in heavy products than in light ones.

From an economic standpoint, differences in net revenues among locations suggest that it is possible to increase revenues by promoting an efficient fertilization program. According to agronomic results in several locations, the best results in terms of net revenues were obtained with NFP treatment. Considering that using nitrogen rates beyond the NFP would restrict access to the economic aids provided by EU agri-environmental measures, from an economic point of view the NFP treatment would definitively become more convenient than N200.

\section{ACKNOWLEDGEMENTS}

This research was funded by Regione Campania, PSR Mis. 124 Progetto FIRE RiBe, DRD n. 89 (June 2014). The authors gratefully acknowledge Manifatture Sigaro Toscano Spa (MST) for the expert evaluation of cured products and Producers Associations ATAS (Associazione Tabacchicoltori Sanniti) and CTS (Cooperativa Tabacchicoltori Sanniti) for technical support.

\section{REFERENCES}

1. Nomisma - Società di Studi Economici: The European Tobacco Sector: An Analysis of the Socio-Economic Footprint, Report 2012, pp. 45. Available at: http://www.nomisma.it/index.php/en/publications/ite $\mathrm{m} / 235$-the-european-tobacco-sector-an-analysis-of-thesocio-economic-footprint/235-the-european-tobaccosector-an-analysis-of-the-socio-economic-footprint (accessed February 2018)

2. Coppola, A. and S. Ianuario: The Effects of Job Training on Farm Incomes: The Case of the Kentucky Tobacco in Benevento Area; Bulg. J. Agric. Sci. 23 (2017) 49-57. Available at: http://www.agrojournal. org/23/01-07.pdf (accessed February 2018)

3. Barnard, C.: Leaf Structure in Relation to Quality in Flue-Cured Tobacco; Aust. J. Agr. Res. 11 (1960) 169185. Available at: http://www.publish.csiro.au/cp/ AR9600169 (accessed February 2018)

DOI: 10.1071/AR9600169

4. Zhang, F. and X. Zhang: Classification and Quality Evaluation of Tobacco Leaves Based on Image Processing and Fuzzy Comprehensive Evaluation; Sensors (Basel), 11 (2011) 2369-2384. Available at: https:/www.ncbi.nlm.nih.gov/pmc/articles/PMC3231 645/pdf/sensors-11-02369.pdf(accessed February 2018) DOI: $10.3390 / \mathrm{s} 110302369$

5. Alliance One International: Glossary Tobacco Terms (2017). Available at: http://www.aointl.com/files/1414/ 5796/7368/Glossary_of_Tobacco_Terms.pdf(accessed February 2018)

6. Sifola, M.I. and L. Postiglione: The Effect of Nitrogen Fertilization and Irrigation on Dry Matter Partitioning, Yield and Quality of Tobacco (Nicotiana tabacum L.) Burley Type; Agriccoltura Mediterranea 131 (1) (2002) 33-43. Available at: http://hdl.handle.net/11588/163253 (accessed February 2018)

7. Lee, Y.J., C.M. Yang, K.W. Chang, and Y. Shen: Effects of Nitrogen Status on Leaf Anatomy, Chlorophyll Content and Canopy Reflectance of Paddy Rice; 
Bot. Stud. 52 (2011) 295-303. Available at: https://ejournal.sinica.edu.tw/bbas/content/2011/3/Bot 523-08.pdf (accessed February 2018)

8. Flower, K.C.: Field Practices; in: Tobacco: Production, Chemistry and Technology, edited by D.L. Davis and M.T. Nielsen, WORLD AGR S, Blackwell Science, Oxford, United Kingdom, 1999, pp.76-103.

9. Davis, D.L. and M.T. Nielsen: Tobacco: Production, Chemistry and Technology; WORLD AGR S, Blackwell Science, Oxford, United Kingdom, 1999. ISBN: 0-632-04791-7

10. Borges, A., R. Morejón, A. Izquierdo, L. Monzón, E. Ortega, and R. Rodés: Nitrogen Fertilization for Optimizing the Quality and Yield of Shade Grown Cuban Cigar Tobacco: Required Nitrogen Amounts, Application Schedules, Adequate Leaf Nitrogen Levels, and Early Season Diagnostic Tests; Beitr. Tabakforsch. Int. 25 (2012) 336-349. Available at: https://www. degruyter.com/downloadpdf/j/cttr.2012.25.issue-1/ cttr-2013-0913/cttr-2013-0913.pdf (accessed February 2018) DOI: $10.2478 /$ cttr-2013-0913

11. Hargreaves, G.H. and Z.A. Samani: Estimation of Potential Evapotranspiration; Journal of the Irrigation and Drainage Division, Proceedings of the American Society of Civil Engineers 108 (1982) 225-230. Available at: http://cedb.asce.org/CEDBsearch/record.jsp? dockey $=0035047$ (accessed February 2018)

12. Doorenbos, J., A.H. Kassam, C.I.M. Bentvelsen, and Food and Agriculture Organization of the United Nations : Yield Response to Water; FAO Irrigation and Drainage Paper No. 33, Food and Agriculture Organization of the United Nations, Rome, Italy, 1979. ISBN: 9251007446

13. Sifola, M.I., B. Cuocolo, and L. Postiglione: Effect of Increasing Nitrogen Fertilization Rate on Yield and Quality of Burley Tobacco (Nicotiana tabacum L.) Grown Under Stressed and Well-Watered Conditions [Campania]; Ital. J. Agron. / Riv. Agron. 2 (1998) $117-125$.

14. Wilhoit, J. and A. Bailey: Facilities and Curing; in: 2013-2014 Kentucky and Tennessee Tobacco Production Guide; Agriculture and Natural Resources Publications, edited by University of Kentucky and University of Tennessee, USA, 2013, pp. 35-41. Available at: https://uknowledge.uky.edu/anr reports/74?utm sour ce $=$ uknowledge.uky.edu $\% 2 \mathrm{Fanr}$ _reports $\% 2 \mathrm{~F} 74 \&$ utm _medium $=$ PDF\&utm_campaign $=$ PDFCoverPages (accessed February 2018)

15. Cooperation Centre for Scientific Research Relative to Tobacco (CORESTA): CORESTA Recommended Methods; CORESTA, Paris, France. Available at: https://www.coresta.org/documents/search/?f\%5B0 $\% 5 \mathrm{D}=$ im_field_technical_document_type $\% 3 \mathrm{~A} 36190$ (accessed February 2018)

16. Sifola, M.I. and L. Postiglione: The Effect of Nitrogen Fertilization on Nitrogen Use Efficiency of Irrigated and Non-Irrigated Tobacco (Nicotiana tabacum L.); Plant and Soil 252 (2003) 313-323. DOI: $10.1023 / \mathrm{A}: 1024784020597$

17. Blackmer, T.M., J.S. Schepers, and G.E. Varvel: Light Reflectance Compared with Other Nitrogen Stress Measurements in Corn Leaves; Agron. J. 86 (1994)
934-938. Available at: https://digitalcommons.unl.edu/ cgi/viewcontent.cgi?referer=https://www.google.de/ \&httpsredir $=1 \&$ article $=1324 \&$ context $=$ agronomyfacpub (accessed February 2018)

18. Hunter, R.S. and R.W. Harold: The Measurement of Appearance; $2^{\text {nd }}$ Edition, J. Wiley and Sons, Inc., New York, NY, USA, 1987. ISBN: 978-0-471-83006-1

19. Kay, R.D., W.M. Edwards, and P.A. Duffy: Farm Management; ${ }^{\text {th }}$ Edition, McGraw-Hill Education, New York, NY, USA, 2016. ISBN-13: 978-0073400945

20. MSTAT-C: A Microcomputer Program for Design Management and Analysis of Agronomic Research Experiments; East Lansing, Michigan State University, MI, USA, 1991.

21. R Development Core Team: R - A Language and Environment for Statistical Computing; R Foundation for Statistical Computing, Vienna, Austria, 2011. ISBN 3-900051-07-0

22. Wickham, H.: ggplot2 - Elegant Graphics for Data Analysis; Springer International Publishing, New York, NY, USA, 2016. DOI: 10.1007/978-3-319-24277-4

23. Jones, J.N., G.N. Sparrow, and J.D. Miles: Principles of Tobacco Irrigation; ARS-USDA Agric. Info. Bull. 228 U.S. Gov. Print. Office, Washington, DC, USA, 1960. Available at: https://naldc.nal.usda.gov/download/ CAT87210419/PDF (accessed February 2018)

24. Moore, J.M. and P.E. Sumner: Irrigating Tobacco; UGA Extension Bulletin 892 (2012). Available at: https://secure.caes.uga.edu/extension/publications/file s/pdf/B\%20892_2.PDF (accessed February 2018)

25. Hutton, R.J., J.J. Landsberg, and B.G. Sutton: Timing Irrigation to Suit Citrus Phenology: A Means of Reducing Water Use Without Compromising Fruit Yield and Quality?; Aust. J. Exp. Agric. 47 (2007) 71-80. DOI: $10.1071 /$ EA05233

26. Ascione, S., C. Ruggiero, and A. Napolitano: Effects of Water Volume and Nitrogen Fertilization on Yield and Quality Traits of Air-Cured Burley Tobacco (Nicotiana tabacum L.); Beitr. Tabakforsch. Int. 24 (2011) 194-206. DOI: $10.2478 /$ cttr-2013-0897

27. Maw, M.M., S. Nakasathien, and E. Sarobol: Responses of Specific Leaf Weight, Biomass and Seed Yield of Soybean to Nitrogen Starter Rate and Plant Density; Kasetsart J. (Nat. Sci.) 45 (2011) 1-11.

28. Wang, D., M.W. Maughan, J. Sun, X. Feng, F. Minguez, D. Lee, and M.C. Dietze: Impact of Nitrogen Allocation on Growth and Photosynthesis of Miscanthus (Miscanthus $\times$ giganteus); Glob. Change Biol. Bioenergy 4 (2012) 688-697.

DOI: $10.1111 / \mathrm{j} .1757-1707.2012 .01167 . x$

29. Pettigrew, W.T., J.J. Heitholt, and K.C. Vaughn: Gas Exchange Differences and Comparative Anatomy Among Cotton Leaf-Type Isolines; Crop Sci. 33 (1993) 1295-1299.

DOI: $10.2135 /$ cropsci1993.0011183X003300060035x

30. Pelivanoska, V., K. Filiposki, and J. Trajkoski: Changes in Anatomic Structure of Burley Tobacco Under the Influence of Irrigation and Fertilization; Beitr. Tabakforsch. Int. 21 (2005) 345-349. DOI: $10.2478 /$ cttr-2013-0800

31. O'Toole, J.C., K. Treharne, M. Turnipseed, K. Crookston, and J. Ozbun: Effect of Potassium Nutrition on 
Leaf Anatomy and Net Photosynthesis of Phaseolus vulgaris L.; New Phytol. 84 (1980) 623-630.

32. Peng, S., A.L. Sanico, F.V. Garcia, R.C. Laza, R.M. Visperas, J.P. Descalsota, and K.G. Cassman: Effect of Leaf Phosphorus and Potassium Concentration on Chlorophyll Meter Reading in Rice; Plant Prod. Sci. 2 (1999) 227-231. DOI: 10.1626/pps.2.227

33. Sims, J.L., S.J. Sheen, C. Grunwald, and W.O. Atkinson: Effects of Nitrogen Fertilization and Stalk Position on Certain Chemical and Physical Characteristics of Three Tobacco Genotypes; Can. J. Plant Sci. 55 (1975) 485-490. DOI: $10.4141 /$ cjps75-074

34. Noodén, L.D.: Senescence in the Whole Plant; in: Senescence in Plants, edited by K.V. Thimann, CRC Press, Boca Raton, FL, USA, 1984, pp. 219-258.

35. Akehurst, B.C.: Tobacco; $2^{\text {nd }}$ Edition, Longman Inc., London, United Kingdom, 1981, (Tropical Agricultural Series), pp. 736.

DOI: $10.1017 / \mathrm{S} 0014479700013958$
36. Sifola, M.I., G. Raimondi, and A. Maggio: Improving the Sustainability of Tobacco Cultivation by Optimizing Nitrogen Fertilization; Aust. J. Crop Sci., in press, 2017.

37. Tso, T. C.: Production, Physiology and Biochemistry of Tobacco Plant; Ideals Inc., Beltsville, MD, USA, 1990, pp. 7-85. ISBN-13: 978-1878670014

Corresponding author:

Maria Isabella Sifola

Department of Agricultural Sciences

University of Napoli Federico II

Via Università 100

80055 Portici (Napoli)

Italy

E-mail: sifola@unina.it 